\title{
AN INTRODUCTION TO \\ THE ALEYRODIDAE OF WESTERN AFRICA (HOMOPTERA)
}

\author{
BY \\ L. A. MOUND \\ British Museum (Natural History)
}

Pp. I13-160; 50 Text-figures

BULLETIN OF

THE BRITISH MUSEUM (NATURAL HISTORY) ENTOMOLOGY Vol. I 7 No. 3

LONDON : 1965 
THE BULLETIN OF THE BRITISH MUSEUM (NATURAL HISTORY), instituted in 1949, is issued in five series corresponding to the Departments of the Museum, and an Historical series.

Parts will appear at irregular intervals as they become ready. Volumes will contain about three or four hundred pages, and will not necessarily be completed within one calendar year.

In I965 a separate supplementary series of longer papers was instituted, numbered serially for each Department.

This paper is Vol. I7. No. 3 of the Entomological series. The abbreviated titles of periodicals cited follow those of the World List of Scientific Periodicals.

(C) Trustees of the British Museum (Natural History) 1965

TRUSTEES OF

THE BRITISH MUSEUM (NATURAL HISTORY)

Issued 23 September, I965

Price Eighteen Shillings 


\title{
AN INTRODUCTION TO \\ THE ALEYRODIDAE OF WESTERN AFRICA \\ (HOMOPTERA)
}

\author{
By L. A. MOUND
}

CONTENTS

\begin{tabular}{|c|c|c|c|c|c|c|c|c|c|c|}
\hline \multicolumn{11}{|c|}{ CONTENTS } \\
\hline INTRODUCTION & $\cdot$ & . & . & . & . & . & . & . & . & I 5 \\
\hline LIST OF SPECIES & DISCUSSED & . & . & . & . & . & . & . & . & I 16 \\
\hline KEY TO GENERA & . $\quad$. & . & . & . & . & . & . & . & . & . $\quad \mathrm{II}_{7}$ \\
\hline SYSTEMATIC TREA & ATMENT & . & . & . & . & . & . & . & . & I I 8 \\
\hline REFERENCES & . $\quad$. & . & . & . & . & . & . & . & . & I 58 \\
\hline
\end{tabular}

S Y NOPSIS

The Aleyrodidae of Africa are very poorly known, only about fifty species being hitherto recorded from the entire continent. Forty species are here recognized from IVest Africa and the Congo, including thirteen new species, one new genus, three new synonyms, and three new combinations. Considerable variation is shown by some species, e.g. Bemisia hancocki, and this is correlated with the host leaf structure in some cases, e.g. Pealius fici and Trialeurodes desmodii. Reasons are given for considering that Bemisia hancocki is not a vector of Cassava Mosaic Virus, and that the spread of this disease and Cotton Leaf Curl was the result of the introduction of $B$. tabaci, the known vector, from India.

\section{NTRODUCTION}

THE generic and specific classification of the sub-family Aleyrodinae of the Aleyrodidae is based entirely on the study of the so-called pupal cases, the exuviae of the fourth instar nymphs. Adults in this sub-family cannot as yet be placed in genera, although this is not true of the Aleurodicinae which are found mainly in the Neotropics. The absence of a systematic study of the adults is partly due to the failure of collectors to obtain adult whitefly along with their related pupal cases, but is also the result of the homogeneity of the adult structure in the Aleyrodinae. Although the adults show remarkably little variation, the nymphs exhibit a considerable range of structure, and a number of quite large genera can be clearly defined. However, the appearance of the pupal cases of several species is now known to vary, depending on the structure of the leaf of the host plant upon which the insect has developed (Russell, I948; Hussey, I957; Mound, I963). This variation usually affects the dorsal setae, in that on hairy leaves these setae are long, but on glabrous leaves they are short. Other features are also affected, particularly the type of marginal crenulation, the form of the thoracic tracheal fold, and the overall shape and size of the body.

About fifty species of whitefly have until now been known from the continent of Africa, although more than seventy species have been recorded from Madagascar 
alone. That this is not a true faunal difference has become evident from collections made in the last few years in Nigeria, Kenya, and Sudan*. The family is clearly well represented throughout the continent, and this paper has been drawn up to indicate how inadequate is the available information on the occurrence of the species, to provide a means of recognizing the genera, and a basis from which further studies may be made. The magnification is indicated in the figures by a line $0.1 \mathrm{~mm}$. in length. All the species recorded from West Africa and the Congo are referred to here, and if possible redescribed. The genera Corbettia and Aleuropteridis however are only treated briefly as they have recently been revised elsewhere. Thirteen new species and one new genus are described, with three new synonyms and three new combinations. Forty species are now recognizable from the area.

Unless stated to the contrary, the material used in this study is deposited in the British Museum (Natural History), and this incudes the type material of the African species described by both Corbett and Dozier. Most of the recent material has been collected by Dr. V. F. Eastop (V.F.E.), or the author (L.A.M.) and his assistants, E. A. James (E. A. J.) and M. O. Ezeigwe (M.O.E.). Dr. Eastop spent eighteen months on secondment from the British Museum to the West African Inter-Territorial Secretariat collecting aphids and whitefly, and the author was employed for eighteen months by the Federal Department of Agricultural Research, Nigeria. This paper is the outcome of work begun then at the request of the Director, Dr. J. M. Waterston, under the direction of the Principal Entomologist, Mr. F. A. Squire.

The author received collections, or assistance whilst collecting, from several workers in West African Departments of Agriculture ; Mr. B. Beck and Mr. J. L. Gregory of the Federal Department, Nigeria; Mr. J. A'Brooke and Mr. G. Farley of North Nigeria; Mr. H. Caswell of the University of Ibadan; Mr. P. Rushton of Sierra Leone, and Dr. C. P. Hoyt of the South Pacific Commission. Dr. Charles Tao of Taipeh loaned a slide of paratypes of Pealius longispinus Tak., and G. R. Cunningham van Someren submitted several large collections from East Africa which have been important in defining certain species. The author wishes to express his gratitude to the Rockefeller Foundation for enabling him to visit the United States National Museum, Washington, and to Miss L. M. Russell of that Museum and Dr. V. F. Eastop of the British Museum (Natural History) for their frequent assistance.

\section{LIST OF SPECIES DISCUSSED}

Synonyms are shown in italics, page references are given to disused combinations.

\section{ACAUDALEYRODES}

africana (Dozier)

citri (Priesner \& Hosny)

alhagi (Priesner \& Hosny)

\section{AFRICALEURODES}

coffeacola Dozier

loganiaceae Dozier

ochnaceae Dozier

vrijdaghii (Ghesquière)

*See also Cohic, F., Cah., O.R.S.T.O.M. (In press).
ALEUROCANTHUS

?woglumi Ashby

?spiniferus (Quaintance)

?citricola (Newstead)

palmae Ghesquière (Cerataphis) (p. I 24)

regis $\mathrm{sp} . \mathrm{n}$.

trispina $\mathrm{sp} . \mathrm{n}$.

ALEUROLOBUS

hargreavesi Dozier

onitshae sp. $\mathrm{n}$.

[New species from Congo.] 
ALEUROLONGA gen. $\mathrm{n}$. cassiae sp. $n$.

ALEUROMARGINATUS tephrosiae Corbett

\section{ALEUROPLATUS} andropogoni Dozier fimbriae sp. n. periplocae (Dozier)

ALEUROPTERIDIS

filicicola (Newstead) douglasi Mound eastopi Mound hargreavesi Mound jamesi Mound

ALEUROTRACHELUS africanus Dozier (p. I I9)

\section{ALEUROTUBERCUI,ATUS} nigeriae sp. $\mathrm{n}$. kusheriki sp. $n$.

\section{ALEYRODES}

africana Newstead (p. I46) filicicola Newstead (p. I 35) periplocae Dozier (p. I34) zimmermanni Newstead (p. I54)

\section{BEMISIA}

tabaci (Gennadius)

golding $i$ Corbett

nigeriensis Corbett

gossypiperda Misra \& Lamba hancocki Corbett

\section{CORBETTIA}

milletiacola Dozier

baphiae Russell indentata Russell grandis Russell graminis sp. $\mathrm{n}$.

\section{DIALEURODES \\ kirkaldyi (Kotinsky) \\ DIALEUROLONGA \\ africana (Newstead) \\ hoyti sp. n. \\ akureensis sp. $n$. \\ emarginata sp. $n$.}

\section{NEOMASKELLIA \\ bergii (Signoret)}

\section{PEALIUS}

fici sp. $\mathrm{n}$.

ezeigwi sp. n.

\section{POGONALEYRODES}

zimmermanni (Newstead)

\section{TETRALEURODES \\ ghesquierei Dozier}

\section{TRIALEURODES}

desmodii Corbett

lubia El Khider \& Khalifer

hargreavesi Corbett

ricini (Misra)

\section{Key to Genera}

I

$-$

2

Lingula broader than long; sub-margin with a series of setae; on Gramineae and occasionally other Monocotyledons

(I) True margin evenly reflexed ventrally, apparent margin with a series of setae; on ferns

ALEUROPTERIDIS (p. I35)

True margin not reflexed evenly if at all

(2) Operculum fills much less than half of orifice; black species

Operculum fills at least half of orifice .

ACAUDALEYRODES (p. I I )

(3) Dorsal disc separated from sub-margin by suture-like fold . . . . . 5

$\begin{array}{llllllllllllllll}\text { Dorsal disc not so separated from sub-margin } & \text {. } & & & & & & & & & & \end{array}$

(4) Sub-marginal folds parallel and longitudinal, not meeting at anterior

ALEUROLONGA (p. I30)

Suture-like folds continuous around anterior sub-margin; pupal case subcircular to oval 
6 (5) Pupal case clear or only weakly pigmented

AFRICALEURODES (p. 120)

Pupal case black

(6) Dorsal disc elevated by vertical sub-margin

- Dorsal disc not elevated, small setae near sub-marginal fold

TETRALEURODES (p. I 55)

ALEUROLOBUS (p. I 26)

8 (4) Thoracic tracheal pores defined as distinct or indistinct pores, orstrongly developed marginal teeth

Thoracic tracheal pores not apparent, or indicated by a few differentiated marginal crenulations

9 (8) Margin or sub-margin with setae on distinct bases; dorsal surface with characteristic circles of papillae

POGONALEYRODES (p. I 54)

No such marginal or sub-marginal setae

Io (9) Caudal furrow broad, operculum conceals lingula ; first abdominal setae absent ; no setae associated with legs; thoracic tracheal pore indistinct; sub-margin with pores distal to a series of tubercles . ALEUROTUBERCULATUS (p. 136)

Not as above

I (10) Vasiform orifice usually large, knobbed lingula exposed; seventh abdominal segment shorter than sixth; first abdominal setae present; usually a stout spine at base of mesothoracic leg; tracheal folds well developed ; sub-margin with a series of pores or papillae, if both then the pores are proximal of the papillae .

DIALEUROLONGA (p. I 46)

Orifice usually small, lingula not exposed; seventh abdominal segment equal in length to sixth ; legs without spines; sub-margin without a series of papillae

DIALEURODES (p. 144)

I 2 (8) No dorsal setae on first abdominal segment .

Paired setae on first abdominal segment (This segment is not visible in Trialeurodes hargreavesi)

I3 (I2) Lingula tip D-shaped; orifice floor dissected by ridges; sub-marginal setae conspicuous

PEALIUS (p. I 5o)

Lingula and orifice floor otherwise; sub-marginal setae inconspicuous or absent

ALEUROPLATUS (p. 132)

I 4 (I2) Less than four pairs of dorsal setae ; sub-margin with a series of pores or papillae

TRIALEURODES (p. I 55)

More than four pairs of dorsal setae

I 5 (I4) Sub-dorsum with paired longitudinal rows of papillae; sub-margin with sixteen pairs of setae .

CORBETTIA (p. I 43)

Sub-dorsum and sub-margin otherwise .

I6 (I 5) Vasiform orifice elongate triangular

BEMISIA (p. I 40)

- Vasiform orifice otherwise . .

I 7 (16) Dorsal setae smąll, inconspicuous, each marginal crenulation with a large pore

ALEUROMARGINATUS (p. I3I)

Dorsal setae large, very conspicuous

ALEUROCANTHUS (p. I 24)

ACAUDALEYRODES Takahashi, I95I

Type-species: Acaudaleyrodes pauliani Tak., I95I.

Pupal-cases of whiteflies of the genus Acaudaleyrodes are easily recognized by the elongate vasiform orifice with a short transversely rectangular operculum. All the described species have been referred to as black with a white waxy marginal fringe. Two species are known from West Africa. 


\title{
Acaudaleyrodes africana (Dozier, 1934)
}

\author{
(Text-fig. I)
}

Aleurotrachelus africanus Dozier, I934.

Acaudaleyrodes africana (Dozier) Takahashi, 1951 : 382.

Pupal case : On lower surface of leaves; dark brown or black; white waxy fringe between one-tenth and one-fifth width of body; probably some similar wax on dorsum. Length $0 \cdot 60-$ $0^{\circ} 75 \mathrm{~mm}$. Breadth $0^{\circ} 45^{-0} \cdot 55 \mathrm{~mm}$.

Margin: Finely crenulate, twenty teeth in $0 . \mathrm{I} \mathrm{mm}$., recurved ventrally, often difficult to observe. Apparent margin broadly crenulate, eight teeth in $0 \cdot \mathrm{I} \mathrm{mm}$. Anterior and posterior marginal setae present, apparently arising ventrally. Minute sub-marginal setae, $3 \mu$ long, six pairs on cephalothorax and one pair on abdominal segments four to seven.

Dorsal surface: Setae on first abdominal segment minute, less than $3 \mu$. Cephalic, eighth abdominal, and caudal setal bases large, the latter close to posterior margin. Sub-dorsum with simple pores, five pairs on cephalothorax, one pair on each of abdominal segments one and three to seven, just mesad of sub-marginal setae. Cephalic tubercle weakly developed, lateral to cephalic seta. Distinctive sub-marginal fold between cephalic tubercle and second abdominal segment. Cephalothorax keeled anteriorly. Transverse moulting suture anterior to thoracicoabdominal suture, curved deeply to posterior then recurved anteriorly. Abdominal segments one to six sub-equal in length, seven about two-thirds of six, eight about twice seven. Rhachis well developed, segmental sutures clear in sub-dorsum. Median tubercles not apparent. Length of vasiform orifice one and a half times breadth $(0.06 \times 0 \cdot 04 \mathrm{~mm}$.), floor with radiating lines of small tubercles. Operculum transverse, one-quarter the length of orifice. Lingula half length of orifice, sharply expanded apically, terminal setae curved.

Ventral surface : Thoracic tracheal folds poorly defined, posterior fold clear. No setae at base of legs. Many small papillae anterior to mouth parts. Abdominal segmentation clearly visible.

Material examined: Syntypes; twenty pupal cases, Congo: Barambu, on Desmodium sp., i.I926 (J. Ghesquière). Also ten pupal cases, Nigeria : Ibadan, under leaf of herbaceous plant, i. I9r4 (W. A. Lambourn).

A. africanus can be distinguished from the other species in Acaudaleyrodes by the absence of setae from the base of the legs, the strongly expanded lingula tip, the finely crenulate recurved margin, and the conspicuous setal bases near the vasiform orifice.

\section{Acaudaleyrodes citri (Priesner \& Hosny, I934)}

Aleurotrachelus citri Priesner \& Hosny, I934.

Aleurotrachelus alhagi Priesner \& Hosny, 1934. syn. n.

Acaudaleyrodes alhagi (Priesner \& Hosny) Russell, I962. syn. n.

Acaudaleyrodes citri (Priesner \& Hosny) Russell, 1962.

A. alhagii was distinguished from $A$. citri by the possession of a broader rhachis with a larger number of median tubercles. The present author has collected both of these forms abundantly on various Leguminous trees and shrubs along the Nile in Sudan and Egypt. The shape of the rhachis is highly variable within any one population, from narrow and trachea-like, forming a strong median ridge, to broad and rounded. This variation also exists in the syntype series. The broad rounded abdominal shape is commonly, although not solely, associated with the presence of an internal hymenopterous parasite. 
A. citri differs from A. africana in the following characters : Margin strongly crenulate (eight teeth in $0.1 \mathrm{~mm}$.), not recurved ventrally; setal bases on dorsal surface not so large ; cephalic tubercles more pronounced; median tubercles of rhachis occasionally in two or more rows ; lingula less expanded apically; meso- and metathoracic legs each with a large conical seta near its base (o. I mm. long).

Material examined: Numerous specimens from Egypt and Sudan, including abundant syntype material of both nominal species from that region at the Egyptian Department of Agriculture, Dokki, Cairo. Twelve pupal cases, SiERra LEONE : Njala, on a leguminous weed, i.I927 (E. Hargreaves). Eight pupal cases, NiGERIA : Samaru, on unknown host, ix. Ig6o (L.A.M.).

Unfortunately, specimens of $A$. pauliani, the type-species described from Madagascar, and $A$. rhachipora (Singh) from India, are not available for study. Material of this genus from India and Pakistan in the British Museum collection cannot be distinguished from $A$. citri. Singh, however, indicated that the lingula of his species was not expanded apically, and so A. rhachipora should be easily recognized.

\section{AFRICALEURODES Dozier, I934}

Type-species: Africaleurodes coffeacola Dozier, I934.

The genus Africaleurodes includes at present species in which the dorsal disc is distinctly separated from the sub-margin by an almost complete furrow. The transverse and longitudinal moulting sutures only reach to this furrow and there is a series of minute setae associated with the margin. It is thus closely related to Aleurolobus, from which it differs in the absence of dark pigmentation and the more complete occlusion of abdominal segment seven in the mid-line. The three species which are included may be separated on the following characters :

I Vasiform orifice elongate-triangular

-. Vasiform orifice sub-cordate

2 Thoracic tracheal pore area a true pore

- Thoracic tracheal pore area a comb of marginal teeth.

A. coffeacola

A. loganiaceae

A. ochnaceae

Africaleurodes coffeacola Dozier, I934

(Text-figs. 2 and 3)

Pupal case : White or very slightly brown, quite flat with no wax. Sub-circular in shape, widest across transverse moulting suture. Margin occasionally prominent in region of thoracic tracheal pores. Not infrequently on upper surface of leaves as well as lower. Female pupal cases probably larger than those of male. Length I.0-I.5 mm. Breadth $0 \cdot 9-\mathrm{I} \cdot 25 \mathrm{~mm}$.

Margin: Smoothly crenulate with faint anastomosing lines extending across sub-margin. Tracheal pores indicated by thickening, occasionally pigmentation, of six to eight marginal crenulations. Paired anterior and posterior marginal setae present ( $25 \mu$ long). Very close to margin fourteen pairs of minute setae (IO-I $5 \mu$ long), seven pairs on both cephalothorax and abdomen including caudal setae. These setae frequently lost in mounting and staining. Submargin with irregular row of simple pores, these vary in diameter from 3 to ro $\mu$ but are usually small. 

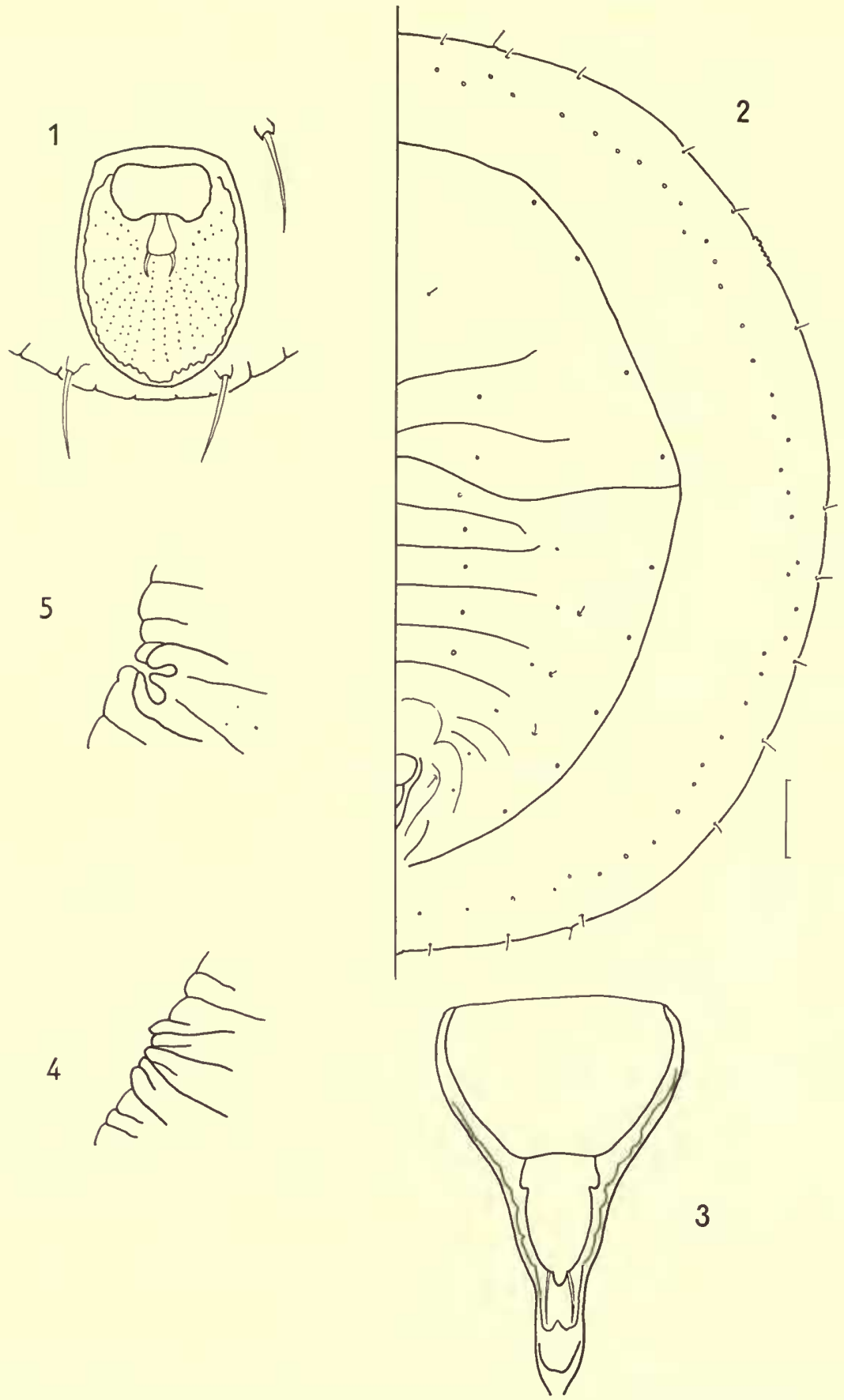

Figs. I-5. I. Acaudaleyrodes africana-vasiform orifice. 2-5. Africaleurodes spp. 2. A. coffeacola-pupal case. 3. A. coffeacola-vasiform orifice. 4. A. ochnaceae-thoracic tracheal pore. 5. A. loganiaceae-thoracic tracheal pore. 
Dorsal disc : Separated from wide sub-margin by distinct furrow, only interrupted at caudal ridges. First abdominal segment apparently without setae, cephalic setae minute, those on eighth abdominal segment a little larger $(5 \mu)$ very close to orifice. Abdominal segments four to six with a pair of sub-dorsal setae, rarely as long as Io $\mu$, frequently appear to be absent. Three paired rows of segmental pores on both abdomen and cephalothorax; on rhachis, subdorsum, and close to sub-marginal fold. Transverse moulting suture reaches sub-marginal fold, abdominal segmentation clear. Anterior margin of segment eight almost confluent with posterior margin of segment six. Abdominal segment seven thus often quite occluded in midline although well developed laterally. Subdorsal area sometimes reticulate. Caudal ridges well developed. Vasiform orifice elongate triangular $(0.10 \times 0.06 \mathrm{~mm}$.) slightly constricted medially, posteriorlateral margins toothed, posterior narrowly open to caudal furrow. Lingula tip exposed, pyriform, with two tubercles proximally. Operculum subcordate, filling wide part of orifice.

Ventral surface : Posterior spiracles large with pair of long fine setae just anterior, anterior abdominal spiracles well developed. Tracheal folds clearly defined by many minute tubercles. Antennae do not extend beyond base of first leg in either sex. Meso- and metathoracic legs with minute basal seta.

Material examined: Syntypes; two pupal cases, CoNGo: Lodja, on Coffea robusta, iii.I928 (J. Ghesquière). Also about eighty pupal cases as follows: Cameroons: Bamenda, on Coffee and Cola, xi.I959 (F. A. Squire); Nigeria : Ibadan, upper leaf surface of Combretum brachteatum and Maesobotrya barteri, vi.I956 (V.F.E.) ; Umudike, on Allophylus africanus, xi-I96o (M.O.E.). SIERRA Leone: Freetown, on ? Rubiaceae, vii.I957 (V.F.E.). SudAN : Yei, on Coffee, iv.Ig62, (F.A. Mitwalli); Wad Medani, on Zizyphusspina-christi,xii. Ig62 (L.A.M.). Seychelles: Aldabra Island, on unknown host, IgI6 (P. R. Dupont).

\section{Africaleurodes loganiaceae Dozier, I934}

$$
\text { (Text-fig. 5) }
$$

Dozier distinguished this species from its congeners on account of its reddishorange dorsal disc. There are three syntypes in the British Museum, collected by J. Ghesquière from Sankuru, Congo Republic, January, I928, on a Loganiaceous plant. Fifteen specimens from Microdesmis pulcrula, at Ibadan, Nigeria, collected by E. O. James in January, I96I may possibly be this species, although this material is colourless and the specimens considerably smaller than the syntypes. It is possible that $A$. loganiaceae can vary in structure in the same way that $A$. coffeacola has been shown to above. A definition of the species must therefore await the collection of further material. The syntype material, however, is fairly distinctive in that although the species is very similar to $A$. coffeacola in general appearance, the tracheal pores have two outer teeth converging around two shorter inner teeth, and the vasiform orifice is sub-cordate.

\section{Africaleurodes ochnaceae Dozier, I934}

(Text-fig. 4)

This species is even less well defined than $A$. loganiaceae. Syntype material in the British Museum consists of two and two half pupal cases from Ochna, at Kole, Congo Republic, collected by J. Ghesquière in January, I928. The vasiform orifice is short 


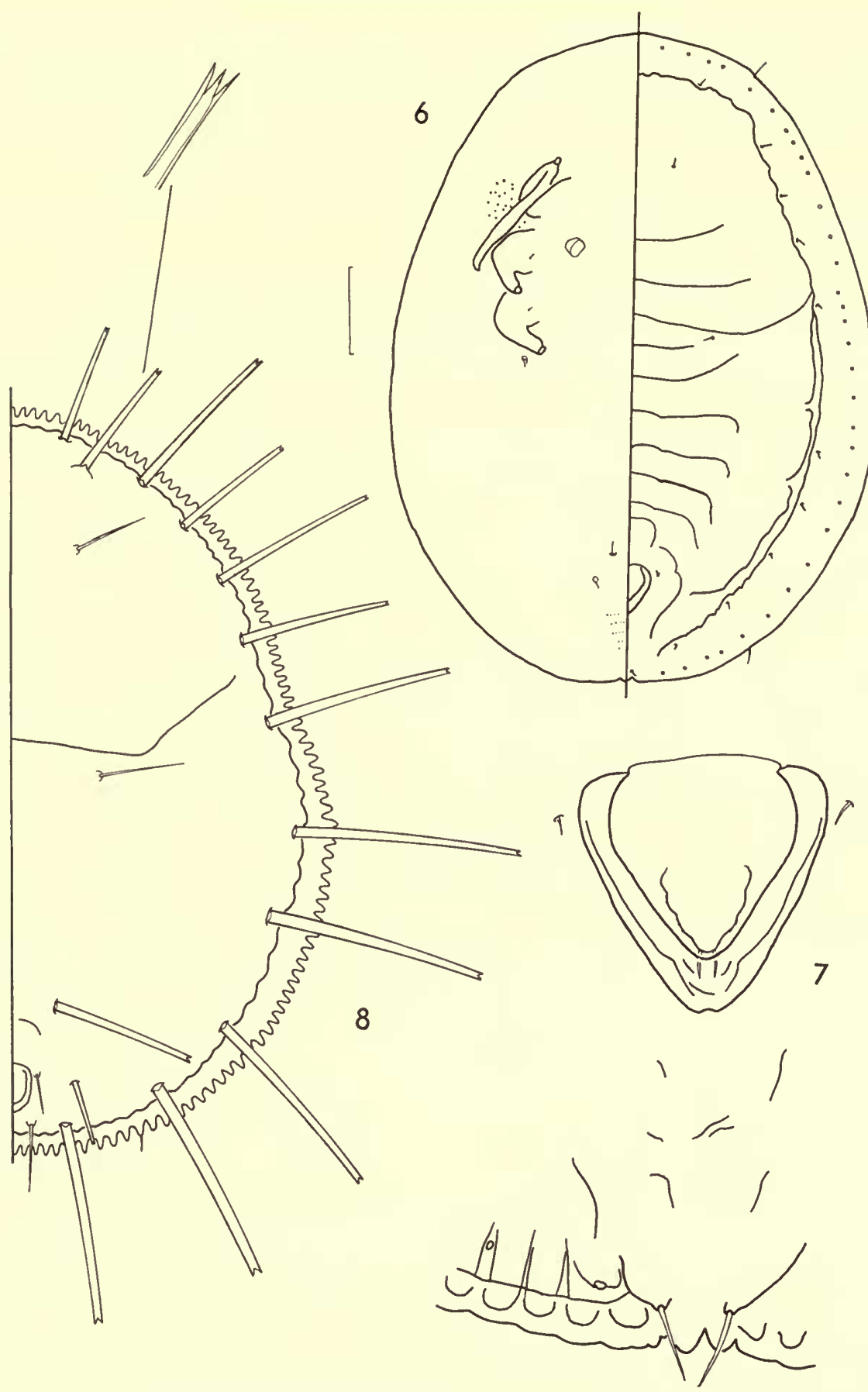

FIgs. 6-8. 6. Aleurolobus onitshae-pupal case (? male). 7. A. onitshae-vasiform orifice and caudal margin. 8. Aleurocanthus regis-pupal case and detail of seta. 
and subcordate as in the previous species, but the tracheal pores are apparently represented by a comb of short teeth. This, however, is by no means certain, as the specimens are very poorly mounted.

\section{Africaleurodes vrijdaghii (Ghesquière, I934)}

Aleurolobus vrijdaghii Ghesquière, I934.

Africaleurodes vrijdaghii (Ghesquière) Russell, I962.

The only descriptive details given for this species are that the larva is " translucid and scarcely visible", and in the accompanying photograph the vasiform orifice is almost completely obscured. The species was recorded as damaging coffee in the Congo.

\section{ALEUROCANTHUS Quaintance \& Baker, I9I4}

Type-species : Aleyrodes spiniferus Quaintance, I903.

The species included in the genus Aleurocanthus all bear on the dorsal surface of their pupal cases a number of long setae which are usually pointed. The two species described here as new are unusual in that in the first the setae have coronate tips, whilst in the second the sides of the setae are minutely spiny. Ghesquière (I934) records $A$. woglumi from Bomba in the Congo on Citrus, but there is some doubt about this record. It seems possible that the species actually found was $A$. spiniferus (A. citricola Newstead). He also describes as new Aleurocanthus palmae, but this is regarded by Risbec (I954) as a synonym of Cerataphis lataniae.

\section{Aleurocanthus regis sp. $\mathrm{n}$.}

$$
\text { (Text-fig. 8) }
$$

Pupal case : $\mathbf{I} \cdot 0 \times 0.8 \mathrm{~mm}$. to $\mathbf{I} \cdot \mathbf{I} \times 0.9 \mathrm{~mm}$. Large, intensely black, on the lower surface of leaves. Has the appearance of a crown; with a white waxy marginal fringe, a marginal ring of black setae each with a drop of golden fluid at its tip, and the centre of the dorsum occupied by rather greyish wax bearing the empty larval skins of earlier instars.

Margin: In mounted specimens apparently with two rows of crenulations. This is probably due to the dorsum being crushed down in the mounting procedure. In life the margin is vertical, elevating the dorsum from the ventral surface as in Tetraleurodes spp., and bearing vertical ridges. Twelve crenulations in $0.25 \mathrm{~mm}$., each with a large pore. Anterior-marginal setae not seen, but posterior-marginals present. Thoracic tracheal pores not developed, but posterior pore indicated.

Dorsal surface : Flat, segmental sutures ill-defined. Seventh abdominal segment as long as fifth and sixth, eighth a little longer. Transverse moulting suture bends anteriorly, to mesothorax, not reaching margin. Caudal and cephalic setae finely pointed, similar setae on abdominal segments one and eight, these setae on distinct tubercles. Paired hollow setae with open coronate tips, apparently secretory, on abdominal segments seven and eight. Six pairs of similar setae on sub-margin of both abdomen and cephalothorax. All setae mounted on distinct tubercles. Four small papillae each with a wax gland, between each sub-marginal setal base. Vasiform orifice rather close to caudal margin, elongate rectangular, an internal projection at posterior margín. Operculum fills orificè, conceals broad spatulate lingula. Caudal furrow not developed. 
Ventral surface: Anterior and posterior abdominal spiracles well developed, apparently connected with each other and with thoracic tracheal folds by a channel. Apparently two pairs of thoracic folds, opposite the two pairs of thoracic spiracles respectively. Posterior fold very short. All these folds indicated by many fine tubercles. Paired setae mesad of, and anterior to, posterior spiracles, also a minute seta at base of each meso and metathoracic leg. Antennae reach to first spiracle.

Holotype pupal case. Nigeria : Ibadan, Moor Plantation, on Combretum sp., i. Ig6r (L. A.M.).

Paratypes, thirty-three pupal cases collected with the holotype.

Due to the extreme density of the black pigment this whitefly proved very difficult to mount and examine. However, the ring of sub-marginal coronate setae, and the absence of large setae from the dorsal disc are quite distinctive. Similar coronate setae had been described from the following species of Aleurocanthus; A.banksiae (Maskell) ; A. hirsutus (Maskell) ; A.rugosa Singh ; A. serratus Qu. \& B. ; A. spinosus (Kuwana). In life, the crown-like appearance is quite remarkable, with a drop of sparkling fluid at the tip of each long seta, and the white surrounding fringe of wax on the leaf.

\section{Aleurocanthus trispina sp. n.}

(Text-figs. 9 and Io)

Pupal case : $0.7 \times 0.4 \mathrm{~mm}$. to $\mathrm{I} \cdot 0 \times 0.7 \mathrm{~mm}$. On the lower surface of leaves, white or pale brown, with very long pale brown setae. Oval in shape, broadest across second abdominal segment, slightly keeled in mid-line.

Margin: With ten long teeth in $O \cdot I \mathrm{~mm}$. Anterior and posterior marginal setae minute, on about the twelfth marginal tooth from mid-line. Tracheal pore areas not differentiated.

Dorsal surface: With thirty-four pairs of setae including long fine caudal setae which are submarginal. Abdomen with nineteen pairs of setae in three rows : on rhachis of segments one to six and eight; on sub-margin of segments two to eight, also caudal setae ; an intermediate irregular row on segments three to six. Fifteen pairs of cephalo-thoracic setae arranged rather similarly : on sub-margin of pro- and mesothorax, with three in cephalic region; medially on meso- and metathorax, and two pairs on cephalic segment; an intermediate row on pro- meso, and metathorax with a group of three setae on cephalic region. The long setae all bear minute lateral spines. Segmental sutures weakly defined, transverse moulting suture deeply recurved around first abdominal segment, does not reach margin. Mesothoracic suture very clear, transverse. Seventh abdominal segment about as long as five and six. Vasiform orifice slightly elevated, elongate rectangular, with an internal posterior projection. Operculum cordate, nearly fills orifice concealing broadly spatulate lingula.

Ventral surface: Sub-margin with about four rows of rectangular markings, absent only at tracheal folds. Mesad of these markings are many raised dots, although the central part of the ventral surface is unsculptured. No setae associated with legs. Antennae bluntly pointed, reaching just posterior to first spiracle, rather longer and more slender than is usual.

Holotype pupal case. Nigeria: Ibadan, Moor Plantation, on Combretum micranthum, xi.I959 (E.A.J.).

Paratypes; five pupal cases with the same data as holotype; also by the same collector at the same site, six pupal cases on an undetermined host, iii. I960, and four pupal cases on Paullinia pinnata, xi.I959. 
This new species, with its very long barbed setae, is distinguished from all the others previously described in Aleurocanthus by the presence of a group of three pairs of long setae on the cephalic region close to the longitudinal moulting suture. Other species sometimes have a group of two pairs of setae on this position. It resembles $A$. hansfordi Corbett in the presence of sub-marginal ventral markings, but differs from that species in the above character and in the shape of the vasiform orifice. However, one of its host plants, Paullinia pinnata is recorded as the type-host of A. hansfordi.

\section{ALEUROLOBUS Quaintance \& Baker, I9I4}

Type-species : Aleyrodes marlatti Qu., I903.

The generic name refers to the trilobed figure formed by the eighth abdominal segment around the vasiform orifice. The orifice is usually cordate and completely filled by the operculum. The dorsal disc is separated from the sub-margin by a suture-like fold, and the sub-margin usually bears a series of setae.

\section{Aleurolobus hargreavesi Dozier, I934}

$$
\text { (Text-fig. II) }
$$

This species differs from other described species of Aleurolobus in that the operculum is not pointed at the posterior margin, and the orifice itself is rather small. Although widespread it is not recognizable from the original description.

Pupal case: Females I.8 $\times$ I.0 mm. Males I.2 $\times 0.7 \mathrm{~mm}$. Black with a white waxy fringe, elongate oval in shape, broadest across first abdominal segment. On leaves of Graminaeae, parallel to leaf veins.

Margin : Crenulate with fine sutures across sub-margin. Tracheal pore areas not differentiated. Anterior and posterior marginal setae present. Sub-margin broad, one-quarter of overall width, separated from dorsal disc by suture-like fold. Sub-margin with fifteen pairs of setae, seven on cephalothorax and eight on abdomen. Setae vary in size and position, particularly in cephalic region where two pairs are frequently not apparent. Sub-margin with a series of simple pores.

Dorsal disc : Cephalic, first and eighth abdominal setae present. Mesothoracic suture marked, extending into subdorsal region, almost meeting transverse moulting suture which curves forward. Thoracico-abdominal suture bends posteriorly to meet short first abdominal segmental suture. Second abdominal suture curved to anterior, third and fourth sutures transverse. Seventh abdominal segment not very short medially, as is common in this genus, as long as segment two, three-quarters as long as six which equals eight. Paired submedian depressions present on each abdominal segment. Eighth abdominal segment not so clearly trilobed as in most members of this genus. Operculum cordate with transverse posterior margin, almost filling orifice. Lingula usually concealed, broadly spatulate with terminal pair of setae. Breadth of caudal furrow one-third its length, with transverse markings.

Ventral surface: Male antennae long, reaching to third leg, female antennae to second leg. Four pairs of spiracles well developed. Paired setae anterior to both rostrum and posterior abdominal spiracles. Meso- and metathoracic legs with a basal seta. These ventral setae rather long and fine.

Adult: (unexpanded specimens from Nigerian pupal cases). Darkly pigmented, wing span about $4 \mathrm{~mm}$. Upper and lower parts of each eye not separated, joined by a narrow neck composed of two facets. Eye facets not different in size. Male abdominal glandular areas small, 


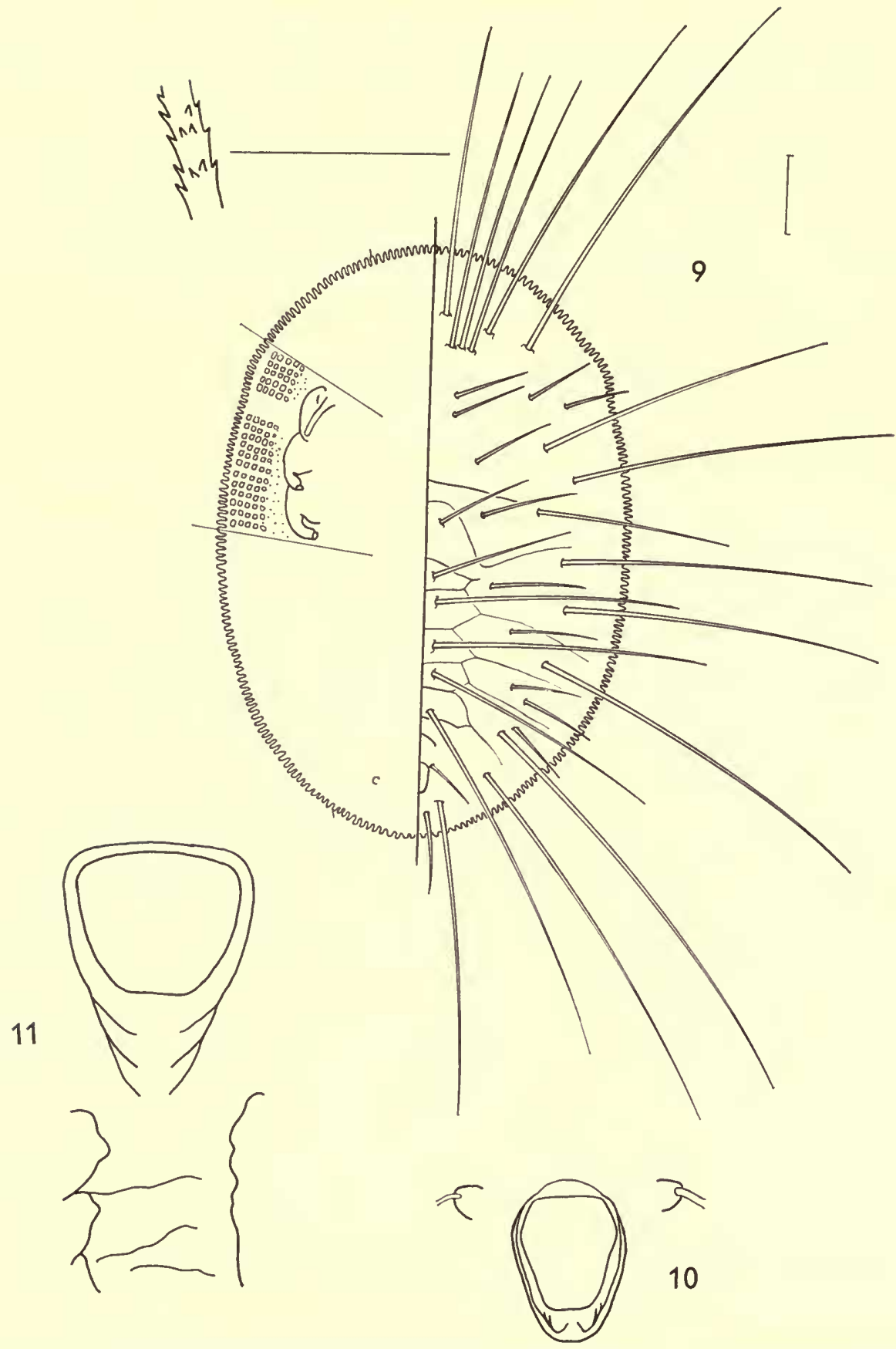

FIgs. 9-II. 9. Aleurocanthus trispina-pupal case and detail of seta. Io. A. trispina-vasiform orifice. I I. Aleurolobus hargreavesi-vasiform orifice and caudal fold. 
less than half length or width of their respective segments. Claspers with strong apical tooth, rounded medial lobe occupies one-quarter of inner length of clasper. Third antennal segment with large sub-apical rhinarium, seventh segment of female with conical rhinarium. Antennae long, seventh segment of male longer than that of female.

Material examined: Seven pupal cases (syntypes) and twenty recently mounted specimens from the original material, UGANDA: Kampala, on Hyparrhenia sp. (a grass), ii.r928 (H. Hargreaves). Nigeria: Minna, on sugar cane, viii.rgro (J. $W$. Scott-Macfie), many specimens including two adult males and seven adult females; Samaru, on grass, x.I956 (V.F.E.), six pupal cases ; Enugu, i.I957 (V.F.E.), twelve pupal cases.

\section{Aleurolobus onitshae sp. $\mathbf{n}$.}

$$
\text { (Text-figs. } 6 \text { and 7) }
$$

Pupal case : On lower surface of leaves, dark brown, with little wax. Oval in shape, broadest across second abdominal segment.

Margin : Crenulate, grooves run across sub-margin from broad and shallow crenulations. Paired anterior and posterior marginal setae present. Caudal setae on dorsal subterminal tubercles, small, barely extending beyond margin. Thoracic tracheal pore areas barely differentiated from margin, posterior pore with two teeth. Sub-margin with ring of small pores one-third of its width from margin, about one pore to every two or three crenulations. Dorsal disc separated from sub-margin by suture-like fold typical of this genus. Close to fold in sub-margin are ten pairs of small setae : on abdominal segments one and four to eight, on pro- and mesothorax and anteriorly and laterally in cephalic region. In one specimen, the fourth abdominal seta of one side is situated in the dorsal disc in the subdorsal region.

Dorsal disc: Abdomen with paired segmental pores, on rhachis, subdorsum and near submarginal fold. Similar pores on cephalothorax. Second abdominal suture bends sharply to anterior and meets first suture. Transverse moulting suture reaches sub-marginal fold, thoracico-abdominal fold not clear. Eighth abdominal segment forms trilobed figure typical of genus. Segment seven short, two-thirds of six, segment eight almost twice length of six. Small cephalic tubercles developed, lateral to these are so-called eyespots. Small paired setae on cephalic, first and eighth abdominal segments. Vasiform orifice typical of genus, triangular with floor dissected by ridges. Operculum pointed to posterior, nearly filling orifice, concealing knobbed lingula. Caudal furrow rather narrow.

Ventral surface : Thoracic tracheal folds defined by ridges and minute tubercles close to mesothoracic leg, but not near margin. Posterior fold defined by rows of elongate tubercles. Paired setae antero-mesad of posterior abdominal spiracles, also anterior to rostrum. A minute seta at base of each meso and metathoracic leg. Female antennae reach to anterior spiracle, male antennae stouter and extend beyond this. Adhesive sacs not heavily sclerotised.

Adult : Body darkly pigmented, wings with black markings. Third antennal segment with large rhinarium distally. Female antenna with segment seven shorter than total length of segments three, four, five and six. Male antenna with segment seven annulated and longer than total length of segments three, four, five and six. Dorsal and ventral portions of eyes almost completely separated by chitinous area bearing very many fine setae. Eye facets equal in size. Lingula only just exceeds vasiform orifice which is half filled by operculum. Male claspers simple with terminal tooth and sub-terminal fleshy lobe.

Holotype \& pupal case. NigerIa : Onitsha, on Phyllanthus floribundus, i.r957, $(V . F . E$.$) .$ 

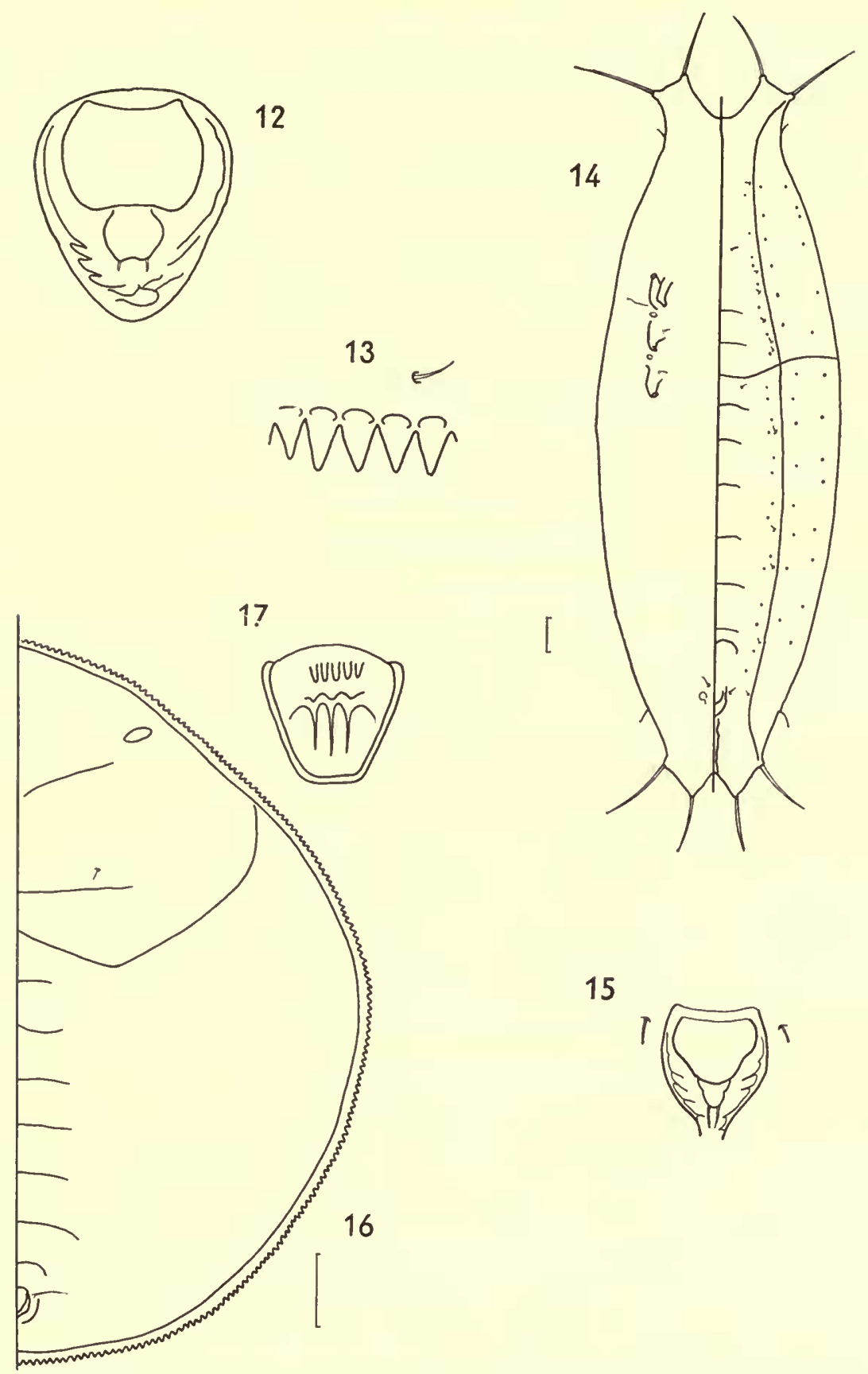

FIGS. I2-I7. I2. Aleuromarginatus tephrosiae-vasiform orifice. 13. A. tephrosiaecaudal margin and seta. I4. Aleurolonga cassiae-pupal case. I5. A. cassiae-vasiform orifice. 16. Aleuroplatus andropogoni-pupal case. I7. A. andropogoni-vasiform orifice. 
Paratypes, fifteen female and six male pupal cases, with the same data as the holotype, together with two female and three male adults dissected from these specimens. Also nine female and two male pupal cases, Nigeria: Ibadan, on Flueggea virosa, i.I96r (L. A. M.).

This species is rather similar to $A$. niloticus $\operatorname{Pr} . \& \mathrm{H}$., but differs from that and other described members of Aleurolobus in the absence of a well defined tracheal pore.

It is of some interest that the adults of these two species of Aleurolobus should both have sexually dimorphic antennae. This is also known to occur in the adults of the following members of the genus, A. barodensis (Maskell), niloticus $\operatorname{Pr}$. \& $\mathrm{H}$., olivinus (Silvestri), philippinensis Qu. \& B., and simulus (Peal). Many whitefly species have three sensoria at the distal end of the third antennal segment. In the adults of $A$. barodensis, hargreavesi, niloticus and onitshae, the only species available to the author, the least distal sensorium is developed into a large clear sensory plate which is reminiscent of the rhinaria of certain aphids.

\section{ALEUROLONGA gen. n.}

Type-species, Aleurolonga cassiae sp. n.

The structure of $A$. cassiae, the new species described below, is quite unlike that of any other previously described whitefly. The elongate shape itself is not particularly unusual, this is found in several other genera such as Aleurocybotus and Dialeurolonga. However the dorsal ridges and the prolongation of the antero- and postero-lateral margins are unique. For this reason a new genus is here defined to contain this single species.

Pupal case : Very elongate, breadth about one-third of length, anterior and posterior lateral margins prolonged making outline rather rectangular. These corners each bear a seta. Anterior and posterior marginal setae present. Dorsal disc elevated by two parallel ridges which connect anterior and posterior corners. A series of small setae in sub-dorsum associated with the ridges. No long dorsal setae. Abdominal segment seven much shorter than six or eight, which are subequal. Tracheal folds faintly indicated, tracheal pore areas poorly defined from margin. Vasiform orifice cordate, lingula tip expanded, partially exposed. Caudal furrow distinct.

\section{Aleurolonga cassiae sp. $\mathbf{n}$.}

(Text-figs. I4 and I5)

Pupal case : $1.6 \times 0.5 \mathrm{~mm}$. to $2.0 \times 0.7 \mathrm{~mm}$. On the lower surface of leaves, usually parallel to margin or midrib. White, with little wax.

Margin: Finely crenulate, tracheal pore areas indicated by faint thickening of marginal crenulations, occasionally accompanied by some markings on dorsal sub-margin. Anterior and posterior marginal setae present, also four pairs of marginal setae on well developed bases, two at anterior and two at posterior corners. Sub-margin with many transverse lines, two rows of small pores, one close to margin one close to longitudinal ridge.

Dorsal disc : Elevated from sub-margin by two longitudinal ridges which connect anterior and posterior corners, with reticulate markings medially. Small paired setae on cephalic, first and eighth abdominal segments, the latter very close to orifice. Similar setae close to, occasionally on, submarginal ridges ; six pairs on cephalothorax, five pairs on abdomen on segments two, four, 
five, seven and eight respectively. A row of pores just mesad of longitudinal ridges. Transverse moulting suture reaches margin. Abdominal sutures not heavily defined, particularly in sub-dorsum. Vasiform orifice elongate-cordate, open at posterior, half filled by operculum which partially conceals expanded spatulate tip of lingula. Caudal furrow very distinct, $0 \cdot \mathrm{I}_{4}-0 \cdot 20 \mathrm{~mm}$.

Ventral surface: Thoracic tracheal folds weakly defined. Anterior abdominal spiracles small, posterior spiracles large with two setae antero-mesad. Antennae short and stout, barely exceeding first leg. A small seta on inner basal area of meso- and metathoracic legs, and a pair of minute setae anterior to rostrum.

2nd instar: Submarginal longitudinal ridges and associated setae as in pupal case, anterior and posterior corners not developed, but the four pairs of marginal setae present.

Holotype pupal case. Nigeria : Moor Plantation, Ibadan, on Cassia siamea, i.Ig6o, (L. A. M.).

Paratypes; seventeen pupal cases, collection data as for the holotype.

\title{
ALEUROMARGINATUS Corbett, I935
}

\section{Type-species : Aleuromarginatus tephrosiae Corbett, I935.}

Three species are at present included in this genus. However the characters given by Singh (I940) in his description of $A$. indica do not separate this species from the type-species, whilst on the other hand examination of type material of $A$. serdangensis Takahashi, I955, in the British Museum indicates that this species bears little relationship to the type-species.

\section{Aleuromarginatus tephrosiae Corbett, I935}

\author{
(Text-figs. I2 and I3)
}

Material examined: Fourteen pupal cases (syntypes), Sierra Leone: Newton, on Tephrosia candida, xi.I932 (E. Hargreaves); four pupal cases, Freetown, on "Leguminous plant," ix.I924 (E. Hargreaves). Six pupal cases, Nigeria : Ibadan, Moor Plantation on Cassia siamea, July, Ig6o (L, A. M.).

The material listed above is only tentatively identified as being conspecific with the syntypes. None of the original specimens appear to be fully mature pupal cases; moreover, most of them have been parasitized and all of them have clearly been treated with caustic potash. Until more material becomes available, from which the variation in pigmentation and number of small dorsal setae can be estimated, an adequate description of this species cannot be given. The available specimens are quite distinctive however. They are about one millimetre in length, almost colourless, with a strongly toothed margin and a pore at the base of each tooth. The transverse moulting suture almost reaches the margin, and the lingula is exposed within the broadly cordate vasiform orifice. The large marginal pores, referred to by Corbett as a second row of marginal teeth, are probably associated with the broad flat waxy fringe which surrounds these insects in life. 
Type-species: Aleurodes quercus-aquaticae Qu., I900.

This genus is not at present well defined. Russell (I958) refers to a few characters which the species to be included do not possess, whilst defining the genus Orchamoplatus ; sub-marginal wax glands absent ; tracheal pore areas not sharply delimited from the rest of the margin; setae absent from the first abdominal segment. However the genus is used in a broad sense to contain a number of forms, the relationships of which are far from clear. Three such species included in the genus here may be separated by the following key.

I Pupal case black

- Pupal case colourless or lightly pigmented

2 Large pore close to each marginal crenulation

- No large marginal pores

A. andropogoni

. 2

A. periplocae

. A. fimbriae

\section{Aleuroplatus andropogoni Dozier, I934}

\section{(Text-figs. I6 and I7)}

Pupal case: Black, slightly pointed anteriorly but broadly round at posterior. Broadest across first abdominal segment, slightly constricted at tracheal folds. Length $I \cdot I 0 \mathrm{~mm}$. Breadth $0.95 \mathrm{~mm}$.

Margin : Strongly crenulate, vertical, elevating dorsal disc from ventral surface, with a pore associated with each crenulation. Tracheal folds not developed, no marginal setae seen.

Dorsal disc : Flat, segmental sutures indicated weakly, abdominal segment eight rather shorter than segments seven or six. Transverse moulting suture bends sharply to anterior, just failing to reach margin. A single pair of short thick setae on mesothorax. Eighth abdominal setae longer than orifice, colourless, arising close to orifice and about one third of its length from its anterior margin. Vasiform orifice very slightly elevated, filled by operculum which obscures lingula. Internally with distinctive sculpture consisting of three teeth with basally a row of pores.

Ventral surface : Tracheal folds narrow, bearing medially many minute tubercles. Abdominal spiracles large. Adhesive organ not very large. A small seta at base of meso- and metathoracic leg.

Material examined : Two syntypes, Congo: Lodja, on Andropogon sp., x.I929 (J. Ghesquière).

No illustration was given of this species in the original publication, and it is not recognizable from the description. A very similar insect has been collected by V. F. E. and L. A. M. on Coconut and Oil Palm Trees at Ibadan, and near Benin, in Southern Nigeria. The form from Palms differs from the syntypes of $A$. andropogoni in the internal sculpturation of the vasiform orifice. This may represent a specific difference, although no other differences have been observed between the two forms. Closely associated with the large black pupal cases on Palm Trees are smaller black oval specimens, the two forms being very similar in the structure of both the vasiform orifice and the margin. It is possible that these smaller pupal cases belong to the males of the species, a suggestion to which some support is lent, by the presence on the same slide as the syntypes of $A$. andropogoni of the ventral surface of a small, oval, black, whitefly pupal case. 


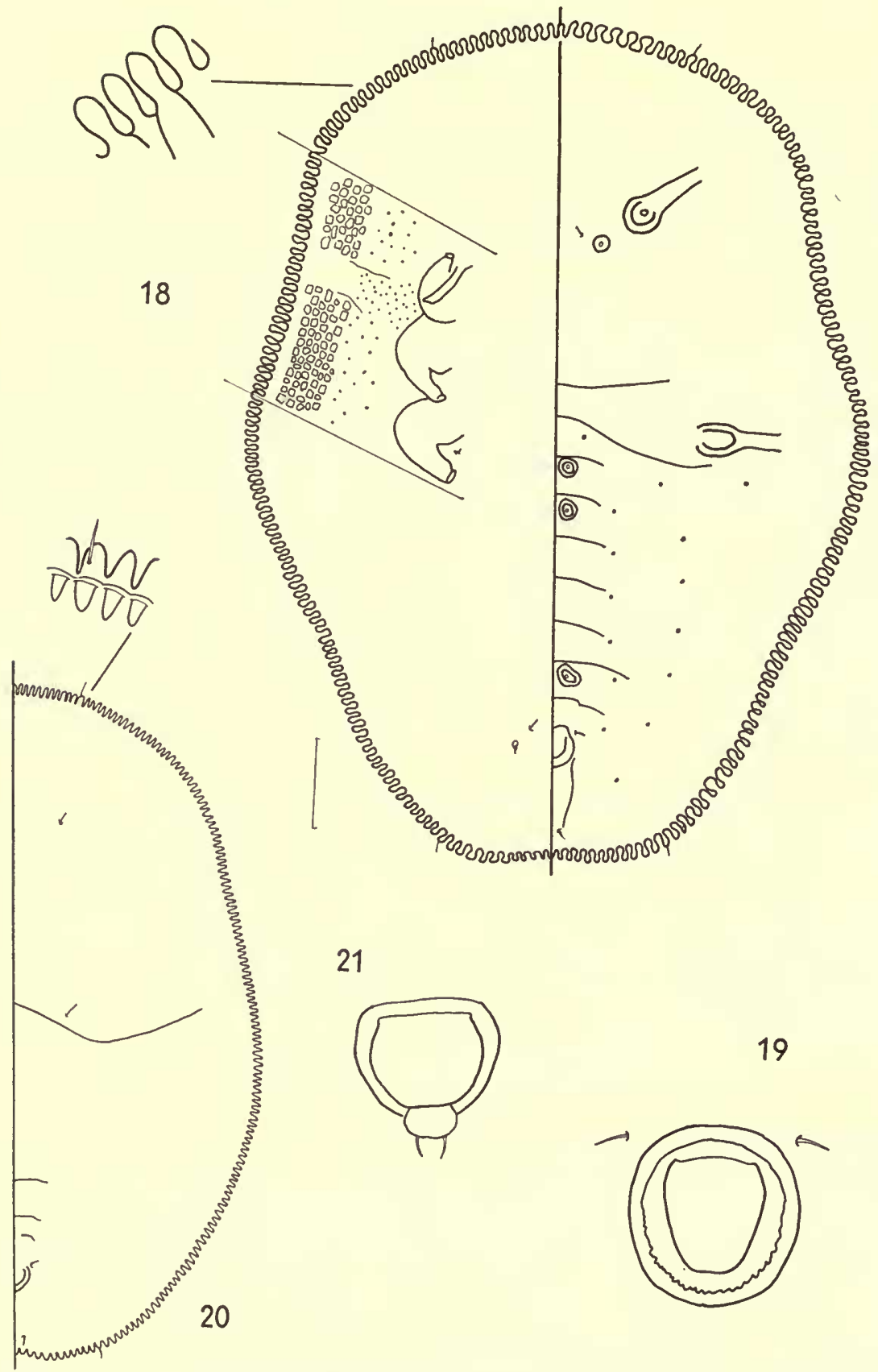

FIGs. I 8-2I. I8. Aleuroplatus fimbriae-pupal case and detail of margin. I9. A. fimbriaevasiform orifice. 20. Aleuroplatus periplocae-pupal case and detail of margin. 2 I. A. periplocae-vasiform orifice. 


\title{
Aleuroplatus fimbriae sp. $\mathrm{n}$.
}

\author{
(Text-figs. I8 and 19 )
}

Pupal case : $0.70 \times 0.50 \mathrm{~mm}$. to $1 \cdot 00 \times 0.75 \mathrm{~mm}$. Males probably smaller than females. Markedly widest across first abdominal segment, anterior and posterior margins rather transverse. On lower surface of leaves, with little wax, white or frequently with brown or black markings.

Margin: With a fringe of distinctive teeth (8-10 in $0.08 \mathrm{~mm}$.), each tooth twice as long as broad. Paired anterior and posterior marginal setae present. Tracheal pore area barely indicated.

Dorsal surface : Cephalic region with a pair of large tubercles, a ridge from each of these to margin. Similar paired ridges on metathorax. Similar tubercles on second, third and seventh abdominal segments, these tubercles with a pore. A pair of similar pores near cephalic setae, but on much smaller tubercles. Ridges, tubercles and rhachis, variously pigmented, occasionally quite black. Dorsal pores and porettes in three rows, "in sub-margin, sub-dorsum and bordering rhachis respectively. Cephalic and eighth abdominal segments with a pair of fine setae. Caudal setae usually small, dorsal, sub-marginal in position. Sub-margin with seven pairs of setae $(8 \mu)$ two pairs on cephalic segment, one pair on prothorax, mesothorax and abdominal segments four, six and seven. Metathoracic suture very strong, transverse. Transverse moulting suture deeply recurved. "Vasiform orifice sub-circular, elongate rectangular operculum threequarters fills orifice concealing (cylindrical?) lingula. Caudal furrow developed, occasionally with irregular tubercles near posterior margin.

Ventral surface : Sub-margin usually with many rectangular markings, interrupted only at tracheal folds. Mesad of these many raised dots. Ventral abdominal setae barely mesad of posterior spiracles. No setae seen at base of legs.

Holotype pupal case. Nigeria: Moor Plantation, Ibadan, on Cassia siamea ii. Ig6r (L. A. M.).

Paratypes; Many pupal cases with the same host and locality data on various occasions i-vi.I96r (E.A.J. \& L. A. M.). A single third instar nymph was also taken on Tecoma stans, GHana : Tafo, v.I957 (V.F. E.).

This species has remarkable marginal teeth which distinguish it from most other whitefly. The dorsal pores on tubercules are also unusual in appearance, and the variable pigmentation associated with them and the rhachis can be rather confusing in a short series of specimens.

\section{Aleuroplatus periplocae (Dozier, I934) comb. n.}

(Text-figs. 20 and $2 \mathrm{I}$ )

Aleyrodes periplocae Dozier, 1934.

Pupal case : Length 0.75 to $0.95 \mathrm{~mm}$. Breadth 0.5 to $0.7 \mathrm{~mm}$. Males probably smaller than females. Colourless, flat, broadest across second abdominal segment, rectangular at posterior. On leaf, with broad waxy fringe one-quarter of the width of the dorsum.

Margin : Crenulate ( 16 in $0.1 \mathrm{~mm}$.), a large wax-secreting pore at base of each crenulationreferred to by Dozier as a second row of teeth. No tracheal pore differentiated. Anterior and posterior marginal setae present, caudal setae sub-marginal in position.

Dorsal surface: Sub-margin not separated. A pair of setae on cephalic, metathoracic, and eighth abdominal segments. Transverse moulting suture does not reach margin. Abdominal sutures very ill-defined, segment seven about two-thirds the length of segments six or eight. Vasiform orifice subcordate, almost filled by rectangular operculum. Lingula tip expanded, protrudes from posterior of orifice. 
Material examined : Syntypes ; ten pupal cases poorly mounted on one slide, and six specimens on leaves, Congo: Barambu, on Periploca nigrescens, viii.I925 ( $J$. Ghesquière).

This species is most distinctive when seen on the host plant, due to the broad waxy fringe. When mounted for study however, the pupal cases are most undistinguished. The margin recalls that of Aleuromarginatus, although the extruded knobbed lingula is like that of Aleurotulus. The species agrees with Aleuroplatus in the absence of setae on the first abdominal segment, the lack of the thoracic tracheal pores, and the absence of sub-marginal pores.

\section{ALEUROPTERIDIS Mound, I96I}

Type-species : A. douglasi Mound, I96r, here regarded as being synonymous with Aleyrodes filicicola Newstead, I9II, syn. n.

This genus, similar to Tetralicia in that the true margin is recurved ventrally, was described for four species all collected on ferns. Both dark and light species are included and these can be separated by the following key :-

I Five pairs of sub-marginal setae anterior to thoracic tracheal pore .

A. eastopi

- Four pairs of sub-marginal setae anterior to thoracic tracheal pore

2 Dorsal setae reach margin .

- Dorsal setae small, not reaching margin

3 Dark brown to black

Lightly pigmented

- 2

A. hargreavesi

- 3

A. jamesi

A. filicicola

Aleuropteridis filicicola (Newstead, IgII) comb. n.

Aleyrodes filicicola Newstead, r9I I.

Aleuropteridis douglasi Mound, I96r. syn. $\mathbf{n}$.

This species is not recognizable from its description, but type material on leaves was obtained from the Zoological Museum, Humboldt University, Berlin. These specimens have the dorsal disc almost entirely pigmented, with a pale margin, and no wax is present. The type specimens of $A$. douglas $i$ have the pigment restricted to the mid-line, and there is a small marginal waxy palisade. No further differences could be found between the two groups of specimens, and they are here considered to be conspecific.

Material examined : Syntypes on leaves, and five pupal cases subsequently stained and mounted. TANGANYIKA: Sigithal near Amani, on ferns, viii.I902 (Zimmermann), Zoological Museum, Berlin, and British Museum (Natural History).

Holotype and paratypes of $A$. douglasi. England : Kew Gardens, Greenhouse, on Pteris togoensis, and Cyclosorus dentatus, I89r (J.W. Douglas).

\section{Aleuropteridis eastopi Mound, I96I}

Material examined : Holotype and eight paratypes, also four pupal cases on a slide bearing the same data as the type series but only recently found in the British Museum collection; Ghana : Tafo, on Ferns, I2.v.r957 (V.F.E.). 
Aleuropteridis hargreavesi Mound, I96I

Material examined: Holotype and three paratypes; Sierra Leone : Freetown, on Bush Fern, ix.I924 (E. Hargreaves).

\section{Aleuropteridis jamesi Mound, I96I}

Material examined: Holotype and five slides bearing paratypes, also abundant mounted and unmounted material from the same locality; NigERIA : Moor Plantation, Ibadan, on Pteris togoensis, near a stream on various dates from I957 to I96I (E. A.J.).

\section{ALEUROTUBERCULATUS Takahashi, 1932}

Type-species : Aleurotuberculatus gordoniae Tak., I932.

This is a fairly well defined genus of about fifty species, described mainly by Takahashi or Corbett from the Far East. The margin bears a series of tubercles, the vasiform orifice is open posteriorly to a wide caudal furrow, and each thoracic tracheal pore is a small circular pore usually difficult to see as it faces laterally.

\section{Aleurotuberculatus nigeriae sp. $\mathrm{n}$.}

(Text-figs. 22 and 23)

Pupal case : $0.7 \times 0.5 \mathrm{~mm}$. to $0.8 \times 0.6 \mathrm{~mm}$. On the lower surface of leaves, white, with little wax. A little brown pigment sometimes on first abdominal segment and metathoracic tubercles. Broadest across metathorax, deeply emarginate at posterior.

Margin: Finely and regularly crenulate (40 in $0.1 \mathrm{~mm}$.). Paired anterior and posterior marginal setae present. Caudal setae on dorsal sub-marginal papillae. Tracheal pores like those of other members of the genus, smooth, shallow emarginations, posterior pore set in a deep cleft.

Dorsal surface : Sub-margin with about forty-seven tubercles on each side, varying considerably in degree of development, frequently ill-defined in region of thoracic tracheal pore. Ridges sometimes run from tubercles toward margin, particularly in cephalic region. Longitudinal moulting suture with apparently scalloped edge due to row of small papillae. Similar papillae define head of developing adult, and occur as transverse rows on posterior margin of each segment from prothorax to seventh abdominal segment. Two pairs of large tubercles on subdorsum of prothorax and metathorax, a single pair of similar tubercles on mesothorax and first abdominal segment. Smaller tubercles may occur sub-medially on each abdominal segment. Sub-dorsum granular. Median abdominal tubercles usually trilobed. Paired cephalic setae sometimes extend to margin of pupal case on antero-lateral margins of cephalic tubercles. When minute, these setae are situated on postero-lateral margins of cephalic tubercles. Eighth abdominal setae minute. Vasiform orifice sub-circular, emarginate at posterior. Operculum similar in shape nearly fills orifice, conceals cylindrical lingula. Caudal furrow very distinct, 0.04 to $0.06 \mathrm{~mm}$.

Ventral surface: Tracheal folds indistinct. Anterior abdominal spiracles clearly visible, a pair of setae antero-mesad of posterior spiracles. No setae observed at base of legs.

Holotype pupal case. Nigeria : Moor Plantation, Ibadan, on Psidium guajava, xii. Ig6o (M. O. E.). 


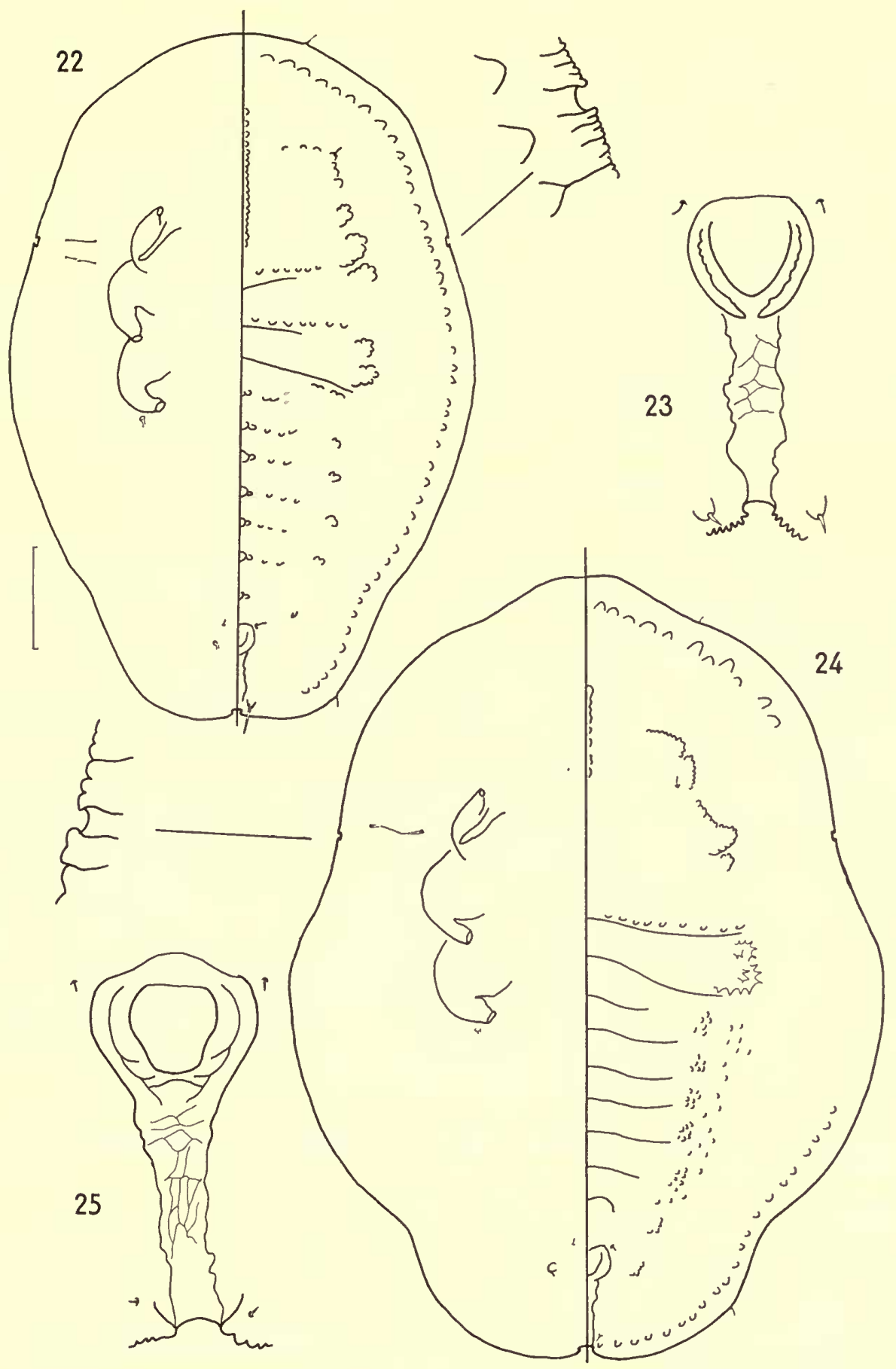

Figs. 22-25. 22. Aleurotuberculatus nigeriae-pupal case and detail of thoracic tracheal pore. 23. A. nigeriae-vasiform orifice and caudal margin. 24. Aleurotuberculatus kusheriki-pupal case and detail of thoracic tracheal pore. 25. A. kusheriki-vasiform orifice and caudal margin. 
Paratypes; twenty-six pupal cases collected with holotype. Six pupal cases Nigeria: Ibadan, on Ficus asperifolia, i.Ig6o (M.O. E.); seven pupal cases, Ibadan, on Diospyros monbuttensis x.I959 (E.A.J.).

This species was also collected commonly by V. F. Eastop on Guava at Ibadan, ii-iv,xi.I956, and this collector also found one pupal case on Tecoma sp., GHANA : Tafo, v.I957. Six pupal cases collected from an unknown plant, Nigeria: Bida, ix. I960 (L. A. M.) are probably the same species.

The sculpturation of the dorsal surface is rather variable in this species. In some specimens the sub-dorsal abdominal tubercles are absent, and the sub-marginal tubercles and transverse rows of papillae are much reduced. This species differs from others described in the genus by the combination of its segmental transverse rows of papillae and elongate shape. It differs from $A$. kusheriki, described below, in the position of the cephalic setae anterior or lateral to the cephalic tubercles.

\section{Aleurotuberculatus kusheriki sp. $\mathrm{n}$.}

(Text-figs. 24 and 25)

Pupal case : $0.6 \times 0.5 \mathrm{~mm}$. to $0.9 \times 0.6 \mathrm{~mm}$. On the lower surface of leaves, white, broadest across first abdominal segment. Constricted at tracheal folds and at seventh abdominal segment. Slightly emarginate at posterior fold.

Margin : Finely but irregularly crenulate (30 in $0.1 \mathrm{~mm}$.). Paired anterior and posterior marginal setae very small. Caudal setae minute on dorsal sub-terminal tubercles. Thoracic tracheal pores typical of genus but the emarginations may be very shallow or absent, the pore only distinguishable in such cases as a smooth portion of the crenulate margin. Posterior emargination smaller than in $A$. nigeriae.

Dorsal surface : Sub-marginal tubercles imperfectly developed, except in caudal and cephalic regions, probably up to fifty on each side. Longitudinal moulting suture bordered by delicate sculpturation. This lace-like sculpturation is typical of the larger tubercles of this species, head region of developing adult defined by similar markings. Two pairs of large tubercles occur on the pro- and metathorax, and one pair on the mesothorax and first abdominal segment. Similar tubercles indicated on each succeeding abdominal segment, most strongly developed on eighth segment. Median abdominal tubercles similar in structure to thoracic tubercles. Sub-dorsal region with many papillae. Transverse rows of papillae on pro- and mesothoracic sutures. Paired cephalic setae small, mesad of cephalic tubercles, between these and prothoracic tubercles. Eighth abdominal setae minute, anterior to orifice. Sixth and seventh segments subequal in length, two thirds of eight. Vasiform orifice wider than long, rounded laterally. Operculum nearly fills orifice, concealing lingula. Caudal furrow distinct, 0.05 to $0.08 \mathrm{~mm}$.

Ventral surface: As in previous species.

Holotype pupal case. NorTh Nigeria : Kusheriki, on undetermined plant, ix. $\operatorname{Ig60}(L . A . M$.).

Paratypes; seven pupal cases collected with the holotype.

This species is characterized by the lace-like sculpturation of the dorsal tubercles, and the small papillae on the sub-dorsum. It is similar to $A$. lithocarpi Tak. from which it differs in the size and disposition of the dorsal setae. It is close to Aleuroclava complex Singh, but differs in the deeper posterior tracheal cleft and the presence of thoracic tracheal pores. 

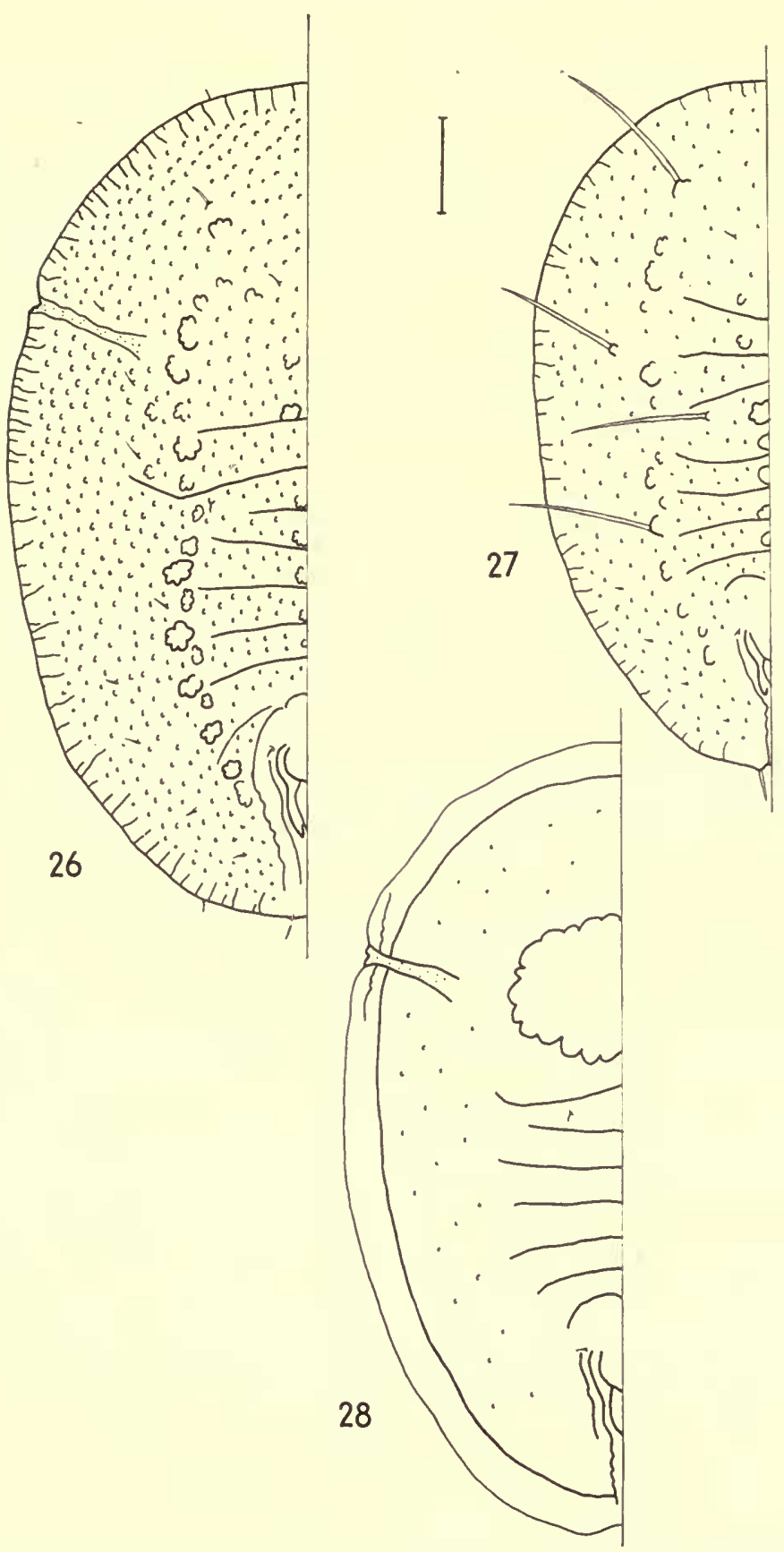

Figs. 26-28. Bemisia hancocki. 26. Pupal case. 27. Pupal case from hairy leaf. 28. Parasitized pupal case. 


\section{BEMISIA Quaintance \& Baker, I9I4}

Type-species: Aleyrodes inconspicua Qu., I900, a synonym of Bemisia tabaci (Gennadius, I889) Russell, I958.

The species included in this genus have an elongate-triangular vasiform orifice, with a spatulate lingula. In view of the synonymies given by Russell (I958) there are now only two recognizable species from West Africa. These can be separated by the following characters.

A Caudal setae less than half length of caudal furrow; transverse markings in caudal furrow

B Caudal setae more than half length of caudal furrow; no transverse markings in caudal furrow

\section{Bemisia tabaci (Gennadius, I889)}

(Text-fig. 3I)

The host range of this species is very great, and the structure of the pupal cases varies depending on the host plant upon which it has developed (Mound, I962 \& I963). Included here as synonyms are $B$. golding $i$ and $B$. nigeriensis, described by Corbett (I935) from Ibadan, Nigeria, on Cotton and Cassava respectively, also B. gossypiperda Misra \& Lamba, recorded from the Congo by Ghesquière (I934) as variety mosaicivectura nov. The adults of this species act as the vectors of leaf curl viruses on Cassava, Cotton, Tobacco, and Peppers in West Africa.

\section{Bemisia hancocki Corbett, I936}

(Text-figs. 26 to 30 )

Pupal case : $0.98 \times 0.72 \mathrm{~mm}$. to $0.67 \times 0.45 \mathrm{~mm}$. Males probably smaller than females. On the lower surface of leaves, white with very little wax. Oval in shape, broadest across metathorax, slightly tapered to posterior.

Margin : Smooth to finely but irregularly crenulate (I 8 in $0.1 \mathrm{~mm}$.), with faint lines extending across sub-margin. Anterior and posterior marginal setae present. Thoracic pores usually indicated by slight thickening, and sometimes pigmentation, of up to ten marginal crenulations ; occasionally not evident at all. Thoracic and posterior pore regions slightly emarginate.

Dorsal surface : Original description refers to "a ring of minute sub-marginal spines". These are not present in the specimens from the type series at the British Museum, and the " spines" referred to are apparently small tubercles. Sub-dorsal area typically very granular, delimited from median area by twenty-two large paired tubercles. These sub-dorsal tubercles on abdomen as follows; one on second, and two on third to seventh segments, the first and the last two of the series being small, the remaining pairs each of one large and one small tubercle. Three pairs of similar sub-dorsal tubercles on both meso- and metathorax, two on prothorax, and three in cephalic region. A pair of similar but smaller tubercles sometimes medially on pro- and mesothorax. Median tubercles usually present on first five abdominal segments. All these tubercles occasionally reduced, apparently absent. Sub-dorsal setae on cephalic region, pro-, meso- and metathorax, and abdominal segments four to eight ; those on prothorax and abdominal segments five to eight often closer to margin than to sub-dorsal tubercles, usually less than $3 \mu$ in length. Remaining sub-dorsal setae closer to tubercles than to margin, occasionally elongate, extending beyond body margin. Three pairs of sub-marginal setae occasionally seen in cephalic 

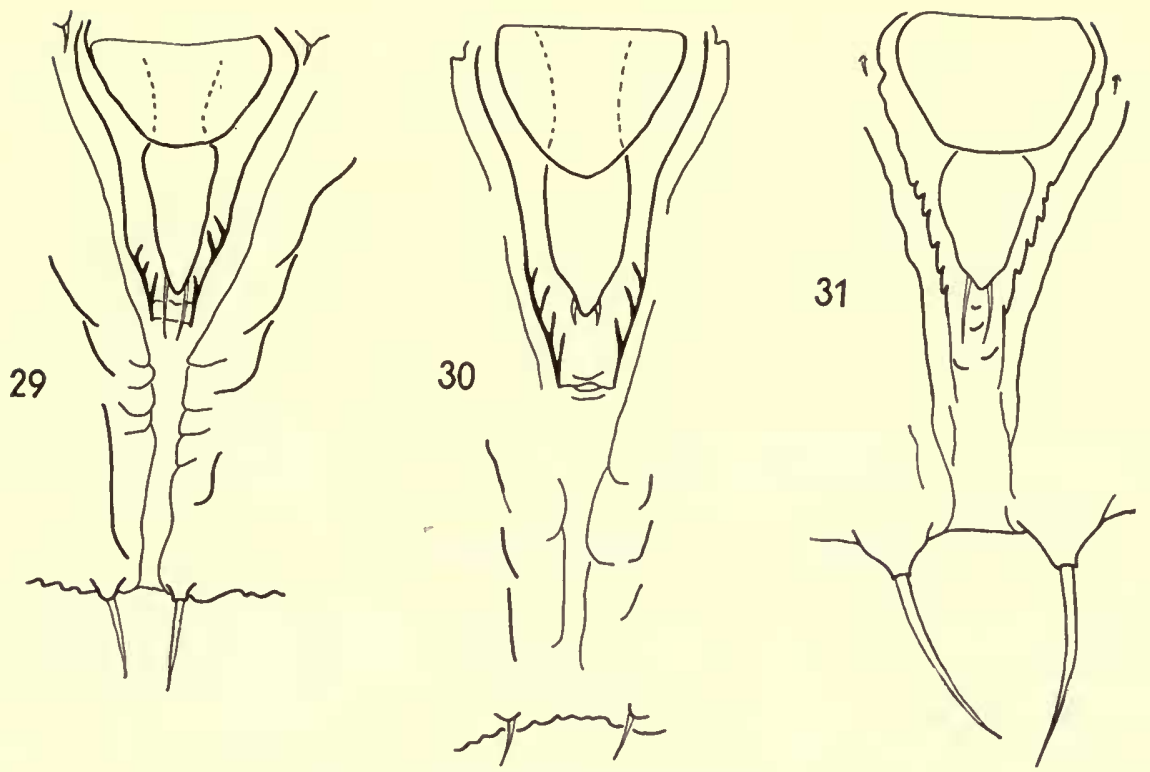

FIGS. 29-31. $29 \&$ 30. Bemisia hancocki-vasiform orifice. 31. B. tabaci-vasiform orifice.

region, $3 \mu$ in length. Dorsal setae on cephalic, first, and eighth abdominal segments, the former two pairs occasionally elongate. Caudal setae not elongate, $40 \mu$, on small tubercles. Transverse moulting suture not reaching margin, anterior margin of segment eight confluent with posterior margin of segment six, only seven segments visible in mid-line. Three paired longitudinal rows of dorsal pores, often difficult to see, in sub-margin, sub-dorsum, and close to rhachis. Vasiform orifice elongate-triangular, slightly constricted behind anterior half, posterior-lateral margins with about four internally projecting ridges, widely open at posterior, length 0.07 to 0. I I mm., breadth 0.05 to $0.07 \mathrm{~mm}$. Operculum sub-cordate, filling about half of orifice. Lingula-tip highly variable, conical to elongate-triangular, or spatulate and barely separated from lingula neck. Caudal furrow well defined, 0.05 to $0.09 \mathrm{~mm}$., with one or more transverse ridges anteriorly. Caudal ridges with transverse markings.

Ventral surface : Tracheal folds rather narrow, defined by many minute tubercles, occasionally not apparent. Posterior abdominal spiracles well developed, with a pair of fine setae. Anterior abdominal spiracles visible. A minute seta at the base of meso- and metathoracic legs. Antennae short with acute tip, barely reaching mesothoracic leg.

Material examined : One pupal case, ?paratype, the only remaining specimen from the type host, UGanda: Eastern Province, on Cotton, I934 (G. L. R. Hancock). Two pupal cases with the same Museum Collection Number as the type, on Vigna catjang, 6.viii.I934 (G. L. R. Hancock). Four pupal cases, Kiyunga, on Cotton, ii.I924 (H. Hargreaves), three pupal cases, Serere, on Groundnut, vi.Ig62 (J.C. Davies).

This species has been taken on Cassava at the following places; Sierra Leone: Njala and Newton, Ig6o (P. Rushton); Nigeria: Bida, x.I96o (L. A. M.) ; Cameroons; Bamenda, xi.I959 (C. P. Hoyt); Sudan : Yambio, iv.I962 (F. A. Mitwalli). Other recorded hosts are Cassia siamea, Cassia petersiana, Zizyphus spina- 
christi, Lonchocarpus sericeus, Chaetacme aristata, Urena lobata, and Bridelia sp. Specimens have been seen from the following places; Natal: Durban; Malawi : Boer River; Kenya : Nairobi ; Sudan : Yambio, Dilling, Wad Medani ; Congo : Stanleyville; Madagascar: Nossi Bè.

The variation shown by $B$. hancocki is very great, almost equal to that of $B$. tabaci. As in the latter species, the most variable characters are the overall size and shape, and the number and definition of the tubercles. This redescription gives the maximum number of tubercles, but within an otherwise typical population, specimens may be found with no dorsal tubercles visible, i.e., with an almost smooth dorsum. The dorsal setae are only rarely elongate, but the microsetae can be very difficult to demonstrate due to their minute size. The shape of the vasiform orifice, with its internal sculpturing and transverse markings at the posterior end, is typical of the species. However the shape of the lingula is highly variable.

A further cause of variation is the presence of Aphelinid parasites in certain specimens. Such parasitized pupal cases, recognizable by the round parasite emergence hole, usually have a smooth margin with a darkly staining sub-marginal line. The parasite pupal case and meconium are not always retained within the host. Parasites from Sierra Leone were identified by B. D. Burks of the United States National Museum as Prospaltella sublutea Silv., and Eretmoceros ?masii Silv.

The relative status of the two species $B$. tabaci and $B$. hancocki is of considerable interest. $B$. tabaci has been recorded from Cassava in most parts of Africa, and it is usually found on the plants as a pure infestation. At the following places it was found however in association with B. hancocki; Njala, Sierra Leone ; Bida, Nigeria ; Bamenda, Cameroons; Yambio, Sudan; Stanleyville, Congo. At four of these sites $B$. tabaci constituted the major part of the total whitefly population, but at Njala this species was virtually replaced by $B$. hancocki. This situation may be correlated with the absence from Njala in I960 of Cassava Mosaic Virus, of which disease $B$. tabaci is the vector. Samples of leaves from the coastal region of Sierra Leone were found however not only to bear $B$. tabaci pupal cases in fair numbers, they also showed typical virus disease symptoms.

A possible explanation of these observations is that $B$. hancocki is not a vector of the mosaic virus, particularly as the disease is almost ubiquitous on Cassava in the high rainfall areas of the West African coast. This virus is known to have spread across Nigeria from East to West between 1930 and I940 (unpublished records of the Federal Department of Agricultural Research, Nigeria). Moreover, Pearson (I949) suggests that another whitefly-borne virus, cotton leaf-curl disease, spread from West Africa to Sudan between 1920 and I930. It seems possible that these sudden movements of virus diseases reflect earlier movements of insect populations. $B$. hancocki may be indigenous to Africa. $B$. tabaci is possibly of more recent introduction, from India through East Africa where Cassava Mosaic was first recorded, and has gradually replaced the original species. 
CORBETTIA Dozier, I934

Type-species : Corbettia milletiacola Doz., I934.

This genus has recently been revised by Russell (r960) from whom the following abbreviated key is adapted. The pupal cases all have a paired longitudinal row of papillae in the sub-dorsum, and sixteen pairs of sub-marginal setae, including the caudal setae. The only species not listed here, C. tamarindi Tak., comes from Madagascar.

I Pro-mesothoracic suture extending to body margin $\quad . \quad$. . . $\quad$ C. grandis

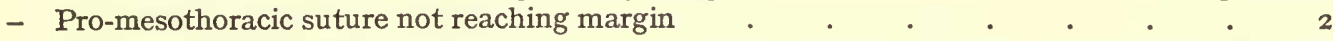

2 Bases of elongate setae nearer sub-dorsal papillae than to margin . . C. indentata

- Bases of elongate setae nearer margin than to sub-dorsal papillae, or no elongate setae . . . . . . . . . . . . . .

3 Eleven long setae on one sub-margin, not all the corresponding setae on opposite side elongate . . . . . . . . . . . C. Craminis

- Six pairs of sub-marginal setae elongate . . . . . . . C. milletiacola

- Two, three, or four pairs of elongate sub-marginal setae _ . . . . C. baphiae

- Only one pair of elongate sub-marginal setae, the caudal setae . . C. tamarindi

\section{Corbettia milletiacola Dozier, I934}

The collection data for the lectotype and one other specimen from the type series in the British Museum are as follows:-Belgian Congo: Kole (Sankuru), on Milletia versicola Welw., 22.i.I928 (J. Ghesquière). However Russell (I960: I29) gives reasons for doubting the accuracy of this data.

New records. Nigeria : Moor Plantation, Ibadan, on Lonchocarpus sericeus and Desmodium lasiocarpus, iv-vii.I956 (V.F.E.), also Olokemeji, near Ibadan, on Mucuna sp., v.r956 (E. A.J.).

\section{Corbettia baphiae Russell, I960}

No type material is available at the British Museum, but two pupal cases determined as this species from the description were removed from plants in the Museum herbarium; TANGanyika: Morogoro, on Cassia auriculata, v.r933. The species was described from Baphia sp., CoNGo : Eala, v.I935, and vii.I936.

\section{Corbettia indentata Russell, I96o}

No material is available at the British Museum. The species was described from Milletia and Tephrosia sp., Congo : Sankuru, Elizabethville, and Eala.

\section{Corbettia grandis Russell, I96o}

No material is available at the British Museum. The species was described from Milletia sp., Congo : Eala, ix.r936. 


\section{Corbettia graminis sp. $\mathrm{n}$.}

(Text-fig. 32)

Pupal case: ?Female $1.60 \times 0.85 \mathrm{~mm}$. ?Male $\mathrm{I} \cdot \mathrm{Io} \times 0.55 \mathrm{~mm}$. Elliptical in outline, but distinctly bilaterally asymmetrical. Lightly but variously pigmented. Sub-dorsal papillae, bases of sub-marginal setae, and abdominal segment two usually brown. Segments seven and eight with or without pigment.

Margin : Smooth or with broad shallow crenulations ( 7 in $0.1 \mathrm{~mm}$.). Tracheal pore area not indicated. Posterior marginal setae present, more than ro $\mu$ in length. Anterior marginal setae not seen. Sub-margin with sixteen pairs of setae, including caudal setae, eight pairs on both cephalothorax and abdomen. Eleven pairs including caudal setae elongate (roo $\mu$ ), on large bases, close to margin ; five pairs, second, fifth, and seventh cephalothoracic, and first and seventh abdominal small $(25 \mu)$, on small tubercles mesad of large setae. Setae of one side always reduced in size. Sub-marginal setae on following segments; cephalic segment four pairs, prothorax one pair, mesothorax two pairs, metathorax one pair, abdominal segments two, three, four, six, and seven each with one pair, segment eight two pairs. Sub-dorsum with radiating anastomosing lines and rows of small tubercles. Sub-medial area demarcated by two longitudinal rows of about seventy-five papillae, each with a minute apical pore. The rows tend to bifurcate close to vasiform orifice. Rhachis with faint transverse rows of small tubercles across abdominal segments, a small pore on either side of each segment, and a pair of setae on cephalic, meso- and metathoracic segments, and abdominal segments one and eight. Segment seven less than half length of six. Orifice sub-circular, length $5^{8} \mu$, breadth $60 \mu$, anterior rim $8 \mu$ long. Orifice three times its length from hind margin of body, a large tooth on posterior median border, internal margin rugose. Operculum transversely rectangular, half filling orifice, with rugose posterior margin. Spatulate lingula exposed, included. Caudal furrow not clearly developed.

Ventral surface: Thoracic tracheal folds not apparent, posterior fold weak. Anterior abdominal spiracles well developed, underlying second abdominal suture. Paired abdominal setae near posterior spiracles. Antennae rather elongate, transversely striate with minute tubercles, in female reaching just posterior to first spiracle, in male almost to second spiracle.

Holotype, ?q pupal case. NIGERIA: Onitsha, at base of grass, I3.i.I957 $(V . F . E$.$) .$

Paratypes, five ? $q$ and five ? $\delta$ pupal cases collected at the same time as the holotype.

This species is quite closely related to $C$. milletiacola, but differs from that species in its much larger size and in the possession of a larger number of elongate submarginal setae. The bilateral assymetry of the available specimens is probably the result of restricted space for growth at the base of the grass on which they were taken. The host record is particularly interesting as all the other species in the genus have been taken on leguminous plants.

\section{DIALEURODES Cockerell, I902}

Type-species : Aleyrodes citri Ashmead, I885.

Species in this genus have well developed pores, usually with internal teeth, the tracheal folds are indicated by many fine tubercles, and the small vasiform orifice often has a row of teeth within its posterior margin. 


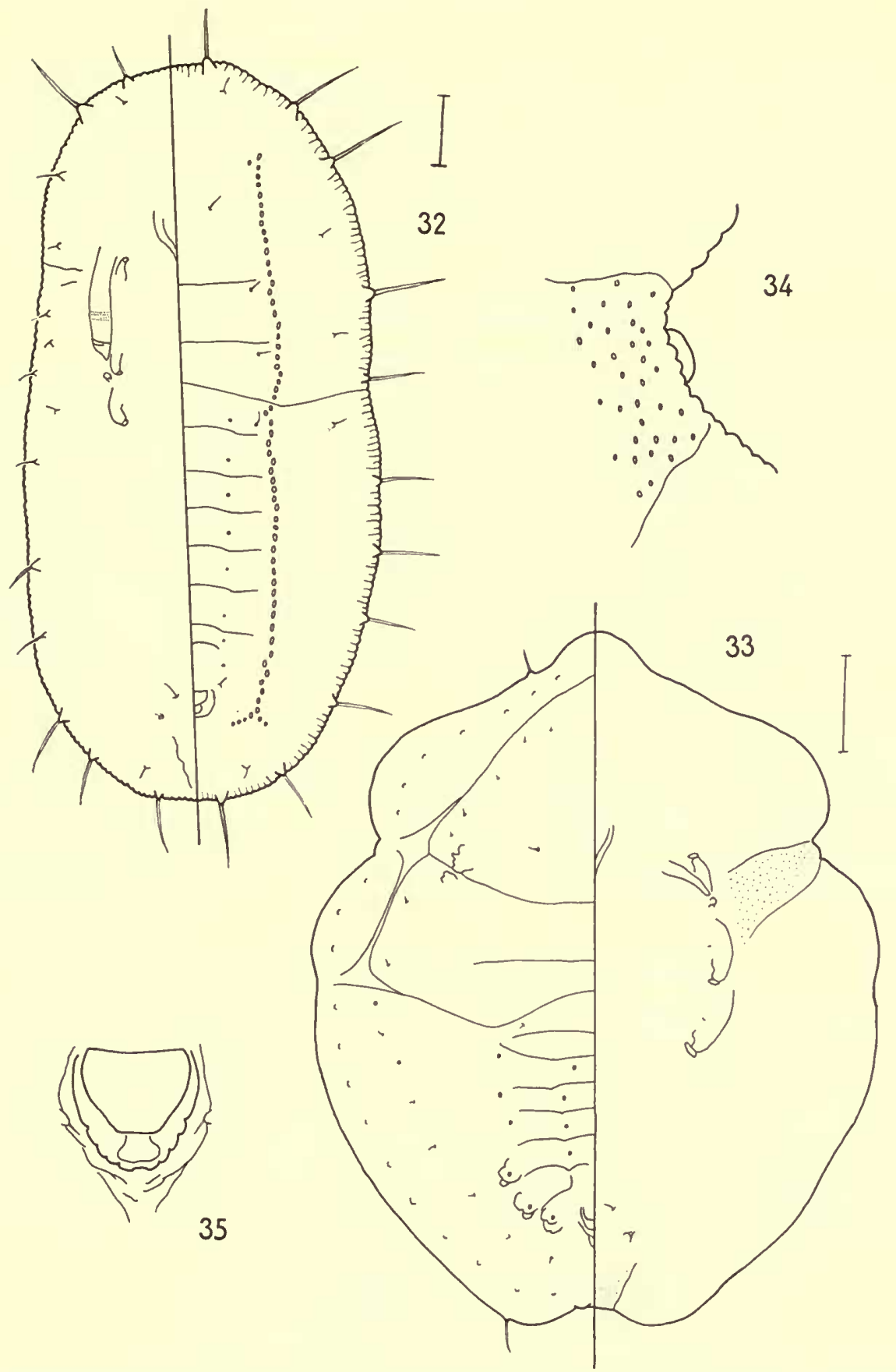

FIGS. 32-35. 32. Corbettia graminis-pupal case (? male). N.B. The dorsal sub-marginal setae also drawn in ventral view. 33-35. Dialeurolonga emarginata. 33. Pupal case. 34. Thoracic tracheal pore. 35. Vasiform orifice. 


\section{Dialeurodes kirkaldyi (Kotinsky, I907)}

This species was described from Jasmine in Honolulu, and an account of its distribution and host range has recently been published by Russell (I964). There are specimens in the British Museum (Natural History) from Allamanda neriifolia, Ghana : Aburi, iii.I922 (W. H. Patterson). The pupal case is slightly constricted behind the thoracic tracheal pores, and the vasiform orifice has an anterior rim more than half the length of the operculum. The eighth abdominal setae are lateral to the orifice.

\section{DIALEUROLONGA Dozier, I928}

Type-species : Dialeurodes (Dialeurolonga) elongata Dozier, I928.

This genus was redefined by Takahashi (r95I) as a full genus, although not all the species included are closely related. It is separated from Dialeurodes by the characters listed in the key, although any one or more of these characters may be absent in a given species. Of the three species here described as new, D. hoyti and D. akureensis seem to be related to $D$. angustata and D. bambusae in the absence of a large spine at the base of the legs and the presence of the caudal setae near the hind margin. $D$. emarginata however is less closely related to the group in the complete reduction of abdominal segment seven, and the anterior extension of the transverse moulting suture. The four species referred to here may be separated by the following key.

I Pupal case twice as long as broad

- Pupal case not so long

2 Tracheal pores indicated by strengthened marginal crenulations

- Tracheal pores are true pores enclosing an internal tooth .

3 Pupal case deeply emarginate; transverse moulting suture bends to anterior and meets in mid-line . . . . . . . . . . D. emarginata

- Pupal case smoothly elliptical ; transverse moulting suture extends nearly to lateral margin .

D. africana

\section{Dialeurolonga africana (Newstead, I92I)}

Aleurodes africana Newstead, I921.

Dialeurolonga africana (Newstead) Takahashi, 1955: 393 .

The pupal cases of this species were described as the food of the larvae of Eublemma scitula, a noctuid moth. The original record was Nigeria: Ibadan, Moor Plantation, on Salacia sp., v.IgI7 (C. O. Farquharson). Type material is not available at the British Museum (Natural History), and the host plant, which was determined at Kew Herbarium, has not been preserved.

\section{Dialeurolonga hoyti sp. $\mathrm{n}$.}

(Text-figs. 38 and 39)

Pupal case : $\mathrm{I} \cdot 2 \times 0.6 \mathrm{~mm}$. On the lower surface of leaves, usually alongside a vein. White with little wax. Elongate triangular in shape, asymmetric, broadest across first abdominal segment. Anterior border transverse, posterior acute. 


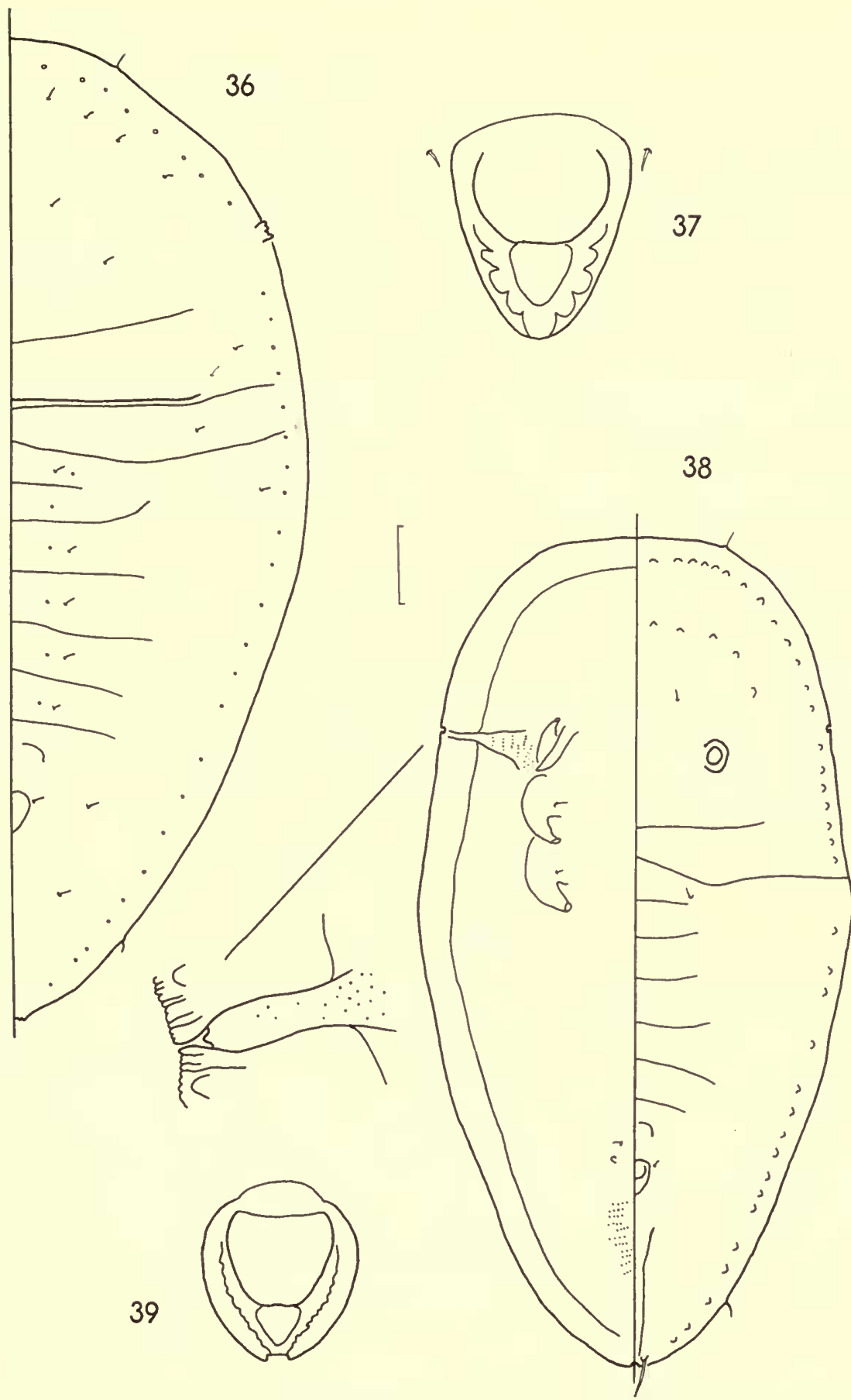

FIGs. 36-39. 36.Dialeurolongaakureensis-pupalcase. 37. D. akureensis-vasiformorifice. 38. Dialeurolonga hoyti-pupal case and detail of thoracic tracheal pore. 39. D. hoytivasiform orifice. 
Margin : Finely crenulate, the crenulations small and regular ( 36 in $0 \cdot 1 \mathrm{~mm}$.) with fine lines extending for a short distance medially across sub-margin. Paired anterior and posterior marginal setae present. Caudal setae on dorsal sub-terminal tubercles. Tracheal pores distinct as pores, appearing triangular in mounted specimens with apex to exterior. Thoracic pores with a single tooth on inner dorsal margin, posterior pore with two such teeth.

Dorsal surface: Sub-margin usually with a series of about one hundred triangular papillae. Five similar papillae in a row on each side in cephalic sub-dorsum. Two paired rows of segmental pores, in sub-dorsum and close to rhachis respectively. A pair of large tubercles dorsal to anterior spiracles. Mesothoracic suture distinct, moulting suture almost transverse, reaching margin. Small paired setae on cephalic, first and eighth abdominal segments. Segment seven about two-thirds length of six or eight. Vasiform orifice sub-cordate, postero-lateral margins rugose, with a large tooth medially. Operculum half fills orifice, exposing D-shaped lingula knob. Caudal furrow very distinct, $0 \cdot 19-0 \cdot 20 \mathrm{~mm}$.

Ventral surface: Sub-marginal region delimited by a suture-like fold interrupted only at tracheal folds. Tracheal folds clearly defined and bearing transverse rows of fine tubercles. A pair of setae mesad of the posterior abdominal spiracles, one or more very small setae near bases of meso- and metathoracic legs. Antennae slender, reaching mesothoracic leg, not sexually dimorphic. The chitin bears the imprint of the stomata and epidermal cells of the host plant.

Adult female: Paronychium with a long angular tip. Terminal antennal segment long and finely tapered.

Holotype pupal case. Nigeria : Agege near Lagos, on Coffee, xi.r959 (C. $P$.
Hoyt).

Paratypes ; eight pupal cases and two adult females collected with the holotype.

This species resembles the type-species in its elongate shape, but differs from it in the transverse anterior margin and the absence of a large pore anterior to the orifice. The elongate terminal antennal segment of the adult is similar to that figured by Singh (I93I) for D. elongata.

\section{Dialeurolonga akureensis sp. $\mathrm{n}$.}

$$
\text { (Text-figs. } 36 \text { and 37) }
$$

Pupal case : $\mathbf{I} \cdot 4 \times 0.8 \mathrm{~mm}$. to $\mathrm{I} \cdot 8 \times \mathrm{I} \cdot \mathrm{I} \mathrm{mm}$. Elongate triangular in shape, broadest across first abdominal suture. Anterior border rather transverse, posterior acute.

Margin : Finely crenulate, lines extending medially across the sub-margin. Paired anterior and posterior marginal setae present. Caudal setae on tubercles antero-laterad of tracheal pore. Tracheal pores distinguished by about six heavily sclerotized marginal crenulations.

Dorsal surface : Sub-margin with a series of tuberculate pores, similar pores scattered throughout dorsum. Mesothoracic suture very clear, straight, extending to sub-margin. Transverse moulting suture does not reach margin. Small paired setae present as follows; four pairs in cephalic sub-dorsum; one pair each on cephalic and prothoracic dorsum ; two pairs on mesothorax and one pair on metathorax in sub-dorsum ; a single pair on sub-dorsum of second abdominal segment and dorsum of remaining abdominal segments. Vasiform orifice cordate, several ridges extend from rugose postero-lateral border over inner surface. Operculum rectangular, more than half filling orifice. Lingula tip exposed, included, broadly pyriform. Caudal furrow very distinct, $0 \cdot 27-0.36 \mathrm{~mm}$.

Ventral surface: Thoracic tracheal folds with few tubercles, but posterior tracheal fold well defined by many transverse rows of fine tubercles. Antennae short with a terminal hook. A pair of fine setae mesad of posterior spiracles. 
Holotype pupal case. Nigeria: Akure, on leaves of unidentified tree, i.I957 (V.F.E.).

Paratypes; eight pupal cases collected with the holotype.

Although this resembles other members of the genus in the presence of a submarginal row of pores and the shape of the orifice, it differs from these species in that the tracheal pore area is composed of a row of teeth and does not form a true pore. Both this and the preceding species, $D$. hoyti, are apparently related to $D$. angustata and $D$. bambusae described by Takahashi from Madagascar.

\section{Dialeurolonga emarginata sp. $\mathbf{n}$.}

(Text-figs. 33-35)

Pupal case : $0.75 \times 0.60 \mathrm{~mm}$. to $0.80 \times 0.75 \mathrm{~mm}$. White, but sometimes with an internal bright orange area medially. Broadest across mesothorax, deeply emarginate at thoracic and posterior tracheal folds, acute anteriorly.

Margin: Smoothly crenulate $(22$ in $0.1 \mathrm{~mm}$.), with faint radial lines across sub-margin. Anterior and posterior marginal setae $30 \mu$ in length, on stout bases. Tracheal pores covered by a smooth rounded lobe $I_{5} \mu$ in length. Caudal setae minute, close to margin.

Dorsal surface: Sub-margin with about forty pores on small tubercles. Three paired rows of similar pores, in sub-dorsum, sub-medially, and bordering rhachis. Sub-median pores on segments six, seven, and eight are raised on large tubercles. Transverse moulting suture does not reach margin, bends forward and meets near anterior end of pupal case, thus forming a triangular emergence hole. Prothoracic suture reaches this moulting suture. Both transverse moulting suture and prothoracic suture are apparently extended to margin. Second abdominal suture bends to anterior. Pockets of eighth abdominal segment confluent with sixth abdominal suture, thus seventh segment apparently occluded in mid-line. Small cephalic setae dorsolateral to rostrum, similar setae on first abdominal segment. Setae of eighth abdominal segment minute, close to orifice and midway along its length. Cephalo-thorax with seven pairs of setae in sub-dorsum, close to moulting suture. Sub-dorsal setae on abdominal segments two, and four to eight. Vasiform orifice cordate, $0.03 \mathrm{~mm}$. long, inner postero-lateral margins toothed. Operculum almost semicircular, three-quarters fills orifice. Expanded tip of lingula exposed, included. Caudal furrow $0.1 \mathrm{~mm}$.

Ventral surface: Tracheal folds broad, with many small tubercles. Anterior abdominal spiracles small. Paired fine setae anterior to rostrum and posterior spiracles. A small seta at base of meso- and metathoracic legs. Antennae thin, reaching to first spiracle.

Holotype pupal case. Nigeria: Olokomeji near Ibadan, on Cola cordifolia, iii.Ig6r (E.A.J.).

Paratypes; five pupal cases collected with the holotype, and nine pupal cases at the same site on Acanthocleista vogelii, iii.rg6r (E.A.J.).

This new species is put in the genus in view of the sub-marginal pores. It differs in shape from all other species described in Dialeurolonga. In general appearance it shows similarities to Dialeurodes shoreae Corbett from Malaya, but that species has a series of setae in the sub-margin, not in the sub-dorsum.

\section{NEOMASKELLIA Quaintance \& Baker, I9I3}

Type-species: Aleyrodes comata Maskell, I896.

The transversely oval vasiform orifice of species included in this genus is quite distinctive. The lingula is broader than long, exposed by the very short operculum. 


\section{Neomaskellia bergii (Signoret, I868)}

A pest of sugar cane in the tropics from Mauritius to the Pacific, this species is also to be found on other members of the Gramineae. It has been recorded from the upper reaches of the River Niger in West Africa by Mimeur (I946), and material in the British Museum has come from the following African territories; Gambia, Sierra Leone, Nigeria, Cameroons, Principe, São Thomé, Sudan, Uganda, Tanganyika, Malawi, and South Africa. In most cases the host is referred to as a grass, but material from Eastern Nigeria was collected on leaves of Raffia Palm.

At Ibadan, Nigeria, colonies of both nymphs and adults were observed on Pennisetum purpureum leaves protected by Crematogaster sjostedti. The ants had built tunnels of earth and plant fragments about one centimetre high and up to ten centimetres long over the colonies of whitefly, which they were apparently soliciting for honeydew. When the ants were prevented from reaching the whitefly, the honeydew accumulated on the leaves and these rapidly became covered by a black sooty mould.

\section{PEALIUS Quaintance \& Baker, I9I4}

Type-species: Aleyrodes maskellii Bemis, I904.

Species included in this genus have the floor of the vasiform orifice dissected by many ridges and the lingula exposed, usually with a D-shaped tip. The typespecies $P$. maskellii has a series of fine sub-marginal setae and a crenulate margin from which the tracheal pore areas are not greatly differentiated. The two species described here may be separated as follows :

A. Orifice and eighth adominal setae in a cordate depression

P. ezeigwi.

B. Orifice and setae not so situated

Pealius fici sp. $\mathbf{n}$.

(Text-figs. 46-48)

Pupal case : White, with a waxy palisade on leaf. Oval, rather tapered to posterior, widest across transverse moulting suture. Length 0.60 to $0.62 \mathrm{~mm}$. Breadth 0.30 to $0.32 \mathrm{~mm}$.

Margin : Smoothly crenulate, on hairy leaves extended vertically and deeply emarginate due to the proximity of leaf hairs during development. Thoracic tracheal pore areas indicated by slightly strengthened crenulations with a small lobe $5 \mu$ long dorsally. Minute anterior and posterior marginal setae present.

Dorsal surface: Eight pairs of sub-marginal setae on both cephalothorax and abdomen. Fifth and seventh pair from anterior small, $5 \mu$, on hairy leaves first abdominal also small. Remaining setae up to $50 \mu$ long, but on glabrous leaves only about $25 \mu$. On glabrous leaves sub-marginal setae in a single row, on hairy leaves (includes holotype) sixth and eighth from anterior often more or less on sub-dorsum, giving appearance of dorsal setae. All the setae on distinct tubercles. Paired dorsal setae on cephalic and eighth abdominal segments, the latter very small. Transverse moulting suture reaches margin, second abdominal suture bends to anterior. Anterior border of segment eight confluent with posterior border of segment six, apparently only seven segments in mid-line. Segmental tubercles weakly developed in subdorsal region. Paired sub-median depressions on anterior margin of meso- and metathorax, and abdominal segments one to six. Five similar depressions in cephalic region. Vasiform orifice 
almost semi-circular but widely open at posterior. Inner surface of orifice and caudal furrow dissected by anastomosing ridges. Operculum sub-rectangular, postero-lateral corners slightly elevated. Lingula exposed, D-shaped tip bears two proximal lobes.

Ventral surface: Thoracic tracheal folds not defined, anterior abdominal spiracles clear. No setae seen at base of legs. Antennae short with a narrow hooked tip.

Holotype pupal case. Nigeria: Ibadan, Moor Plantation, Ficus asperifolia, I3. vii.I960 (M.O.E.).

Paratypes ; four pupal cases collected with the holotype ; twenty-eight pupal cases on Ficus sp., Nigeria: Ibadan, I6.v.I956 (V.F.E.) ; four pupal cases on Ficus asperifolia, Agege near Lagos, viii.I96o (M.O.E.) ; fourteen pupal cases on Ficus asperifolia, Samaru near Zaria, x.I96o (M.O.E.).

The leaves of Ficus asperifolia are very hirsute, whereas the leaves of the plant recorded above as Ficus sp. are described in the collector's note-book as being completely smooth. At first sight the pupal cases from these two sources are quite different, but they are here considered to be conspecific for two reasons. Firstly because not all the specimens from hairy leaves have the sixth and eighth sub-marginal setae on the dorsum, and secondly because this type of variation of pupal cases, depending on the nature of the host plant, is quite widespread in the Aleyrodidae.

This species is closely related to Pealius longspinus Takahashi (I932) described from Ficus beechyana in Taipeh. This latter species differs in having several additional pairs of elongate sub-marginal setae; on the cephalo-thorax, one, three, six, and eight, and on the abdomen, two, three, six, seven and eight. In the paratypes of $P$. longispinus examined by the present author the eighth sub-marginal setae of the cephalo-thorax were not always as far dorsal in position as is indicated by the original figure. Corbettella artocarpi (Corbett, I935b) is closely similar to the form of $P$. fici from glabrous leaves, but unfortunately the material referred to in that publication is not available.

\section{Pealius ezeigwi sp. $\mathrm{n}$.}

(Text-figs. 40-4I)

Pupal case : $0.70 \times 0.50 \mathrm{~mm}$. On the lower surface of leaves, white, with a little wax. Oval in shape, rather transverse at anterior and posterior, broadest across transverse moulting suture, barely constricted at thoracic pore.

Margin: Crenulate, but not regularly so $(20$ in $0.1 \mathrm{~mm}$.). Anterior and posterior marginal setae present. Cephalo-thoracic sub-margin with eight pairs of setae on large setal bases, and abdomen with eight pairs including caudal setae. Thoracic tracheal pores indicated by slight constriction of pupal case and differentiation of marginal crenulations.

Dorsal surface : Flat, with no large setae, but with small cephalic and eighth abdominal setae. Sub-median area weakly defined by a series of segmentally arranged indistinct papillae. Segmental sutures extend into sub-dorsum. Transverse moulting suture reaches margin, dividing dorsum into equal anterior and posterior halves. Second abdominal suture bends to anterior almost meeting transverse moulting suture. Segment seven occluded in mid-line as anterior border of eight is confluent with posterior border of six. Vasiform orifice included within a cordate depression which also includes eighth abdominal setae. Depression longer than distance of orifice from posterior margin of body. Orifice roughly triangular, inner surface clearly dissec- 


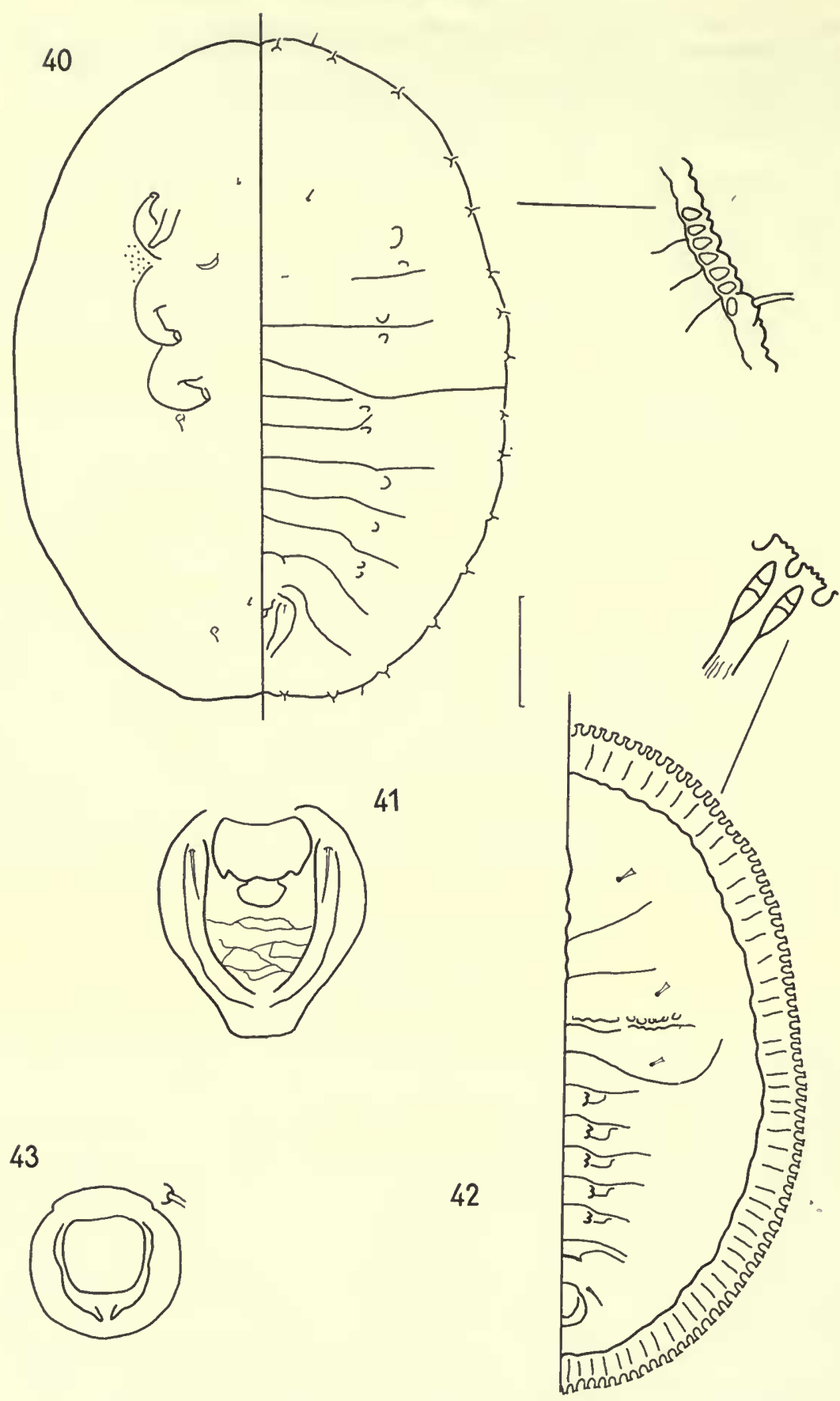

FIgs. 40-43. 40. Pealius ezeigwi-pupal case and detail of thoracic tracheal pore. 4r. $P$. ezeigwi-vasiform orifice. 42. Tetraleurodes ghesquierei-pupal case and detail of margin. 43. T. ghesquierei-vasiform orifice. 
ted into small areas by ridges. Operculum rectangular, broader than long, postero-lateral corners pronounced, two pilose lobes on posterior border. Lingula short but exposed, D-shaped tip with two proximal papillae. Caudal furrow $0 \cdot 04 \mathrm{~mm}$.

Ventral surface: Thoracic tracheal folds indicated by minute dots. Anterior and posterior abdominal spiracles well developed. Small paired setae anterior to rostrum and posterior spiracles.

Holotype pupal case. Nigeria: Ibadan, Bora Farm, Moor Plantation, on undetermined plant, vii. I960 (M.O.E.).

Paratypes ; five pupal cases, Nigeria : Moor Plantation, Ibadan, on Maesobotrya barteri and Alchornia cordifolia, v, vi.I956 (E.A.J.).

This species shows similarities to $P$. kelloggi (Bemis) in its vasiform orifice, marginal setae, and long transverse moulting suture, but differs from that species in that the lingula is not narrowed to the tip. It differs from $P$. misrae Singh in the absence of dorsal setae on the thorax, and in the vasiform orifice being set in a depression.

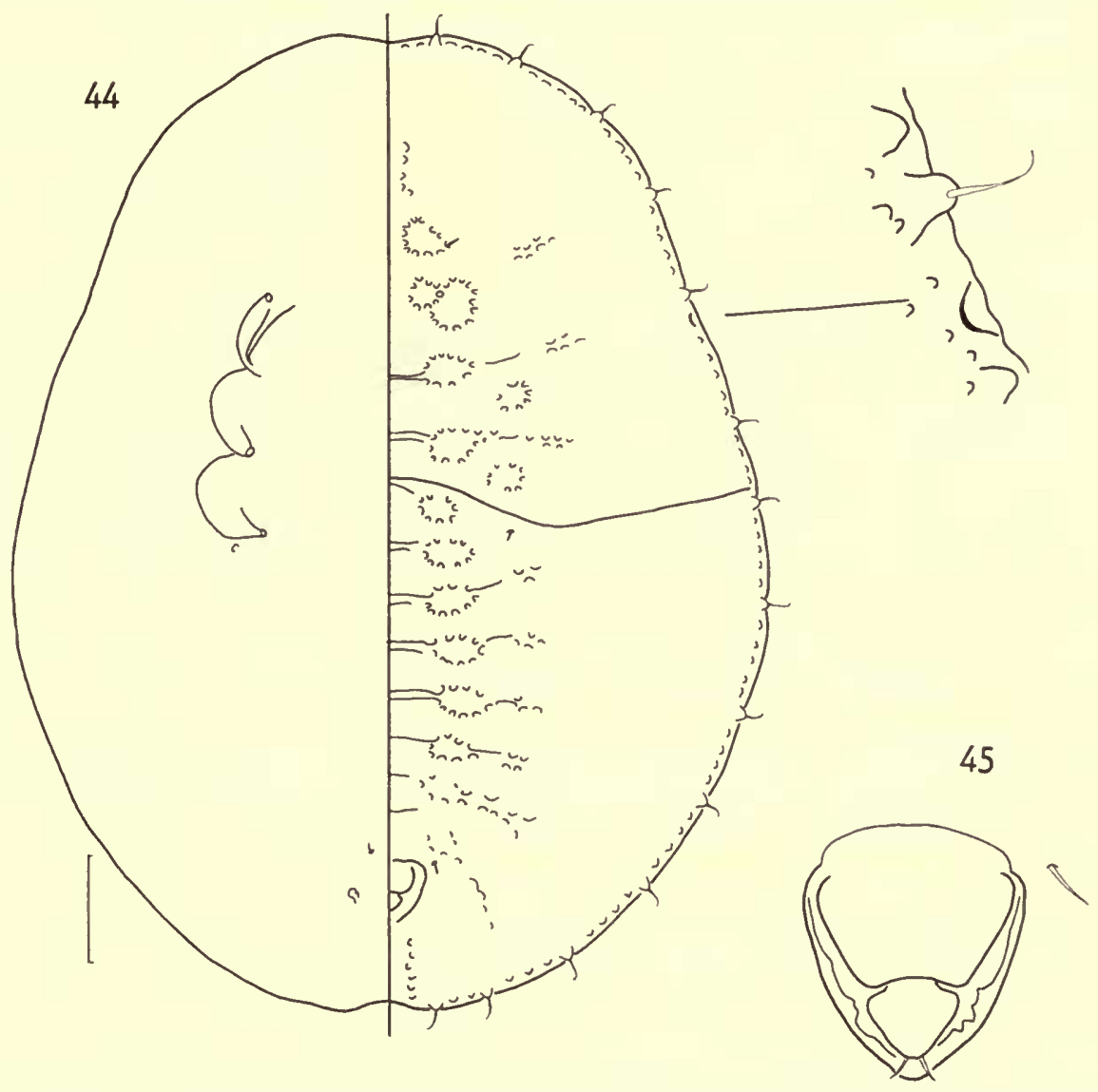

Figs. 44-45. 44. Pogonaleyrodes zimmermanni-pupal case and detail of thoracic pore. 45. P. zimmermanni-vasiform orifice. 


\section{POGONALEYRODES Takahashi, I955}

Type-species: Pogonaleyrodes fastuosa Tak., I955.

This was erected by Takahashi as a monotypic genus. The dorsal surface of the pupal case bears numerous tubercles arranged into a pattern of circles on the intersegmental sutures. The thoracic tracheal pores are rather ill-defined circular pores, and there is a well developed caudal furrow.

\section{Pogonaleyrodes zimmermanni (Newstead, I9II) comb. n.}

$$
\text { (Text-figs. 44-45) }
$$

Aleyrodes zimmermanni Newstead, I9II.

Pupal case : $0.7 \times 0.5 \mathrm{~mm}$. to $0.9 \times 0.6 \mathrm{~mm}$. May occur on both lower and upper surfaces of leaves, occasionally on petioles. White, with a small waxy palisade. Oval to broadly oval in shape, widest across second abdominal segment. Slightly constricted at thoracic tracheal pores, rather more emarginate at posterior pore. Margin slightly thickened, appearing convex.

Margin : Vertical and palisade-like, appearing very finely irregular in mounted specimens. Paired anterior and posterior marginal setae small, ventral in mounted specimens and difficult to demonstrate. Cephalo-thoracic margin with six pairs of setae, abdomen with eight pairs, each mounted on a tubercle. These setae are hooked in mounted pupal cases, but may not be truly chitinous. Between each of the setal bases there are from four to eight similar but smaller tubercles. Typical caudal setae absent. Thoracic tracheal pores present as rather ill-defined circular pores.

Dorsal surface: With many papillae, forming distinctive pattern of circles on intersegmental sutures. About five papillae in posterior part of each circle, four in anterior part. A row of papillae along sixth and seventh abdominal sutures, and along anterior portion of longitudinal moulting suture. Similar papillae sometimes scattered throughout subdorsum. Simple pores on abdomen in four pairs of longitudinal rows. Small paired setae on cephalic, first, and eighth abdominal segments. Transverse moulting suture reaches margin, second abdominal suture curves forward. Seventh abdominal segment scarcely two-thirds length of six or eight which are sub-equal. Vasiform orifice cordate, the posterior lateral margins with a few teeth. Operculum broadly rectangular, rather more than half filling the orifice. Triangular knob of lingula exposed, included. Caudal furrow distinct, $0 \cdot 05-0 \cdot 08 \mathrm{~mm}$.

Ventral surface: Tracheal folds not indicated. Anterior abdominal spiracle visible, no setae at base of legs. Fine paired setae antero-mesad of posterior abdominal spiracles. Antennae short and thin, with an elongate acute tip. Legs rather stout.

Material examined : Syntype series on leaves loaned from Humboldt University, Berlin. Two specimens were mounted and retained at the British Museum. Collection data; TANGANyikA: Amani, on species of Acanthacae, ix. Igo2 (A. Zimmer$\operatorname{mann})$.

Also collected in TANGANyIKA : South Highlands Province, on Coffea arabica at Tukuyu and Rungwe, xii. I957 (R. G. Tapley). Nigeria; Moor Plantation, Ibadan, on unknown plant, xi. I959 and vii. I96o (E. A.J. \& M. O. E.).

This species was described in the genus Aleyrodes but was not recognizable from its description. It resembles Takahashi's figure of the type of Pogonaleyrodes from Madagascar in the form of the dorsal markings, the thoracic pores and the caudal furrow, but it differs in the absence of many small dorsal spines and the operculum 
not filling the orifice. Each pupal case of the type material is surrounded on the leaf by a number of eggs, but otherwise shows no differences from the other specimens listed above. The specimens from Coffee at Rungwe are remarkable in that some pupal cases were found living on the petioles of the leaves.

\section{TETRALEURODES Cockerell, I902}

Type-species: Aleyrodes (Tetraleurodes) perileuca Cockerell, I902.

Pupal cases of species included in this genus have a strongly toothed margin with a vertical sculptured sub-margin elevating the dorsum. Marginal pores are well developed and the species are black in colour.

Tetraleurodes ghesquierei Dozier, 1934

(Text-fig. 42)

Pupal case : Black, broadest across transverse moulting suture, dorsum elevated by vertical sub-margin.

Margin : Each marginal tooth expanded and rugose at tip with a large pore behind in submargin. Sub-margin vertical, strongly sculptured. Tracheal pore areas not differentiated, anterior and posterior marginal setae not seen.

Dorsal disc: Separated from sub-margin by fold, apparently flat. Transverse moulting suture almost meets first abdominal suture, then bends anteriorly to mesothorax. Mesothoracic suture with a row of broad teeth on both anterior and posterior borders. Longitudinal moulting suture not bordered by sculpturing. Prothoracic and cephalic segmental sutures clear, no cephalic tubercles. Abdominal sutures clear into sub-dorsum, segment six three times length of seven, and twice length of eight. Rhachis defined by two pairs of laterally directed teeth on abdominal segments two to six. Two rows of paired segmental pores, near rhachis and in subdorsum respectively. Large setal bases on cephalic, meso- and metathoracic segments bear short, colourless setae with expanded apices. Similar setal bases on eighth segment bear longer acutely tipped setae. Caudal setae very small, close together at edge of disc. Vasiform orifice subcircular with a median internal projection at posterior margin, postero-lateral borders rugose internally. Operculum almost quadrate, lingula obscured. Short, broad, caudal furrow indicated.

Ventral surface: Obscured.

Material examined: Syntype; one pupal case, Congo : Barambu, on Periploca. nigrescens, viii.I925 (J. Ghesquière).

Five pupal cases, Nigeria : Ibadan, on unknown plant, ii. I96o (E.A.J.).

This species is distinguished by the almost trumpet-shaped dorsal setae, and the absence of cephalic tubercles.

\section{TRIALEURODES Cockerell, Igo2}

Type-species : Aleurodes pergandei Quaintance, Igoo.

The North American species of this genus have been revised by Russell (I948), but African and Oriental Trialeurodes species are very poorly known. The ventral surface of the mature pupa is usually swollen, elevating the dorsal surface from the leaf, and there is a vertical waxy palisade. Generally colourless and fragile, the most 


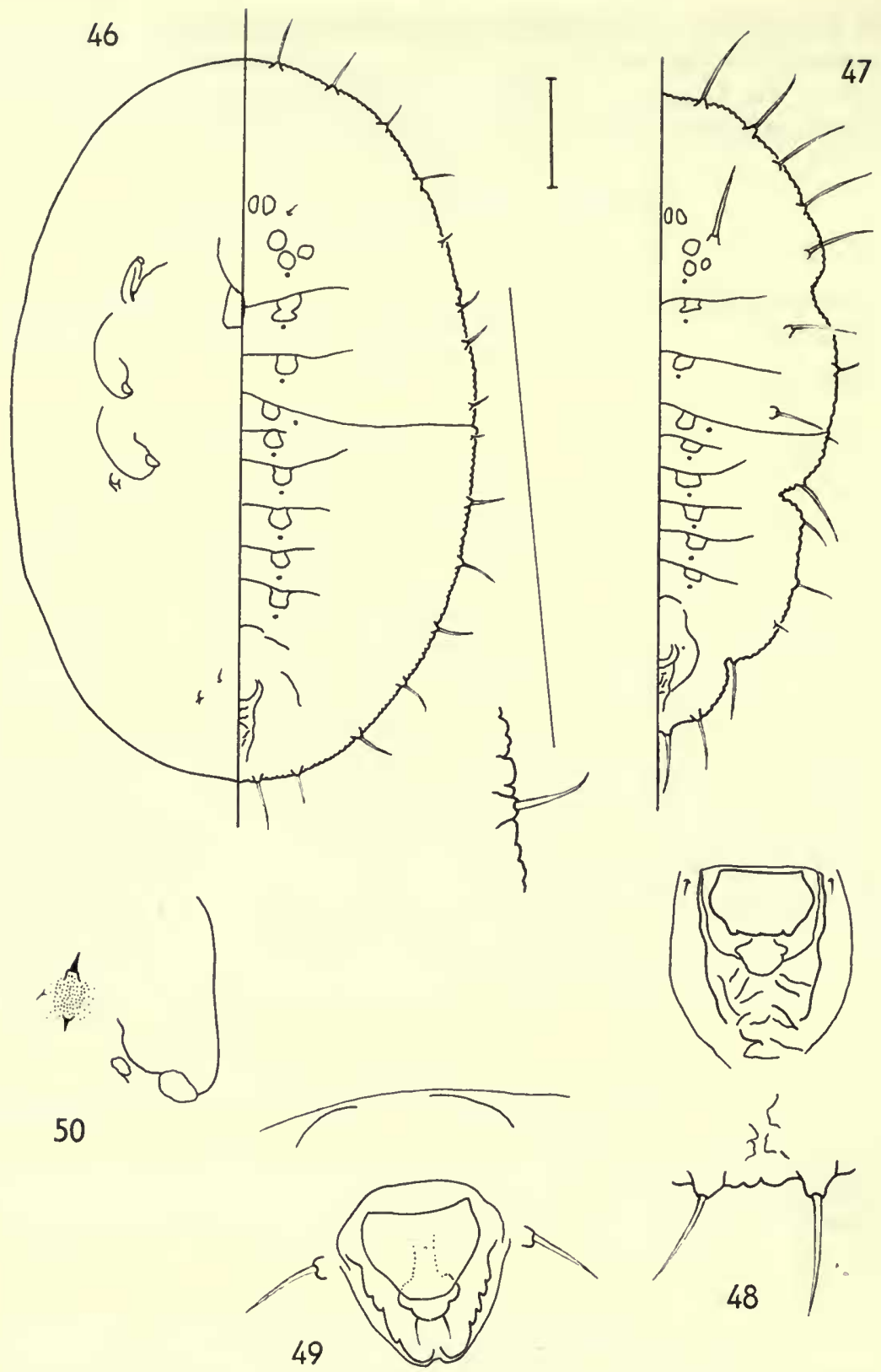

Figs. 46-50. 46. Pealius fici-pupal case from glabrous leaf. 47. P. fici-pupal case from hairy leaf. 48. P. fici-vasiform orifice and caudal margin. 49. Trialeurodes desmodiivasiform orifice and sixth abdominal suture. 50. T. desmodii-mesothoracic leg, spiracle, and associated setae. 
conspicuous characters are the sub-marginal papillae with wax secreting pores, and the trilobed lingula in the cordate orifice. The three species recorded from IVest Africa may be separated as follows:

A Sub-marginal papillae all equal in size

B Sub-marginal papillae not all equal in size

C No true sub-marginal papillae, sub-margin with circular groups of pores
T. ricini

T. desmodii

T. hargreavesi

\section{Trialeurodes desmodii Corbett, I935}

(Text-figs. 49-50)

\section{Trialeurodes lubia El Khider \& Khalifer, I962. syn. n.}

Pupal case : $0.50 \times 0.30 \mathrm{~mm}$. to $0.70 \times 0.45 \mathrm{~mm}$. Smaller specimens probably males, but small specimens also found on hairy leaves. White, with wax palisade and long marginal wax filaments. Elliptical in shape, occasionally on upper surface of leaves.

Margin : Irregularly crenulate $(28$ in $0.1 \mathrm{~mm}$.). Posterior marginal setae almost $20 \mu$ long, anterior marginal setae minute, $5 \mu$ long. Thoracic tracheal pore area barely indicated, posterior pore composed of four or five strong crenulations.

Dorsal surface : Sub-margin with more than sixty papillae, usually between 68 and 72 . On glabrous leaves papillae arranged in a single row, none on dorsum. On hairy leaves papillae apparently in two rows, also a pair of papillae on dorsum of cephalic, prothoracic and second abdominal segments. Sub-marginal disc pores mesad of papillae, caudal setae long, their bases distal to papillae. Transverse moulting suture ends almost opposite its midpoint. Anterior margin of abdominal segment eight confluent or almost confluent with posterior margin of segment six, segment seven thus occluded in mid-line. Paired short setae on cephalic, first and eighth abdominal segments, the latter rather more than half width of orifice in length, arising postero-laterally to anterior margin of operculum. Vasiform orifice cordate, length and breadth about equal, 50 $\mu$, anterior rim 1o $\mu$ long. Orifice emarginate at posterior, margins curve to anterior to meet an internal tooth. Internal lateral margins with fine teeth. Operculum fills two-thirds of orifice exposing tip and one pair of sub-apical lobes of lingula. Caudal furrow particularly developed on pupal cases from hairy leaves, $50 \mu$ to $60 \mu$.

Ventral surface : Meso- and metathoracic legs with two stout setae at base, one large $(5 \mu)$ and one small, on a more heavily sclerotized area, just mesad of this a minute fine seta. Prothoracic leg with one stout seta. Anterior abdominal spiracles not seen.

Material examined: Syntypes; two pupal cases, Sierra Leone: Njala, on Desmodium lasiocarpum, I3.xii.I932 (E. Hargreaves). Three paratypes of T. lubia with about fifty pupal cases from the type series of that species all bearing the same data, SudAN : Shembat-Khartoum, on Dolichos lablab and various hosts, ix. I959 (El Khidir). Nigeria : Ibadan, Moor Plantation, many specimens on Desmodium lasiocarpum, Euphorbia heterophylla, and Corchorus sp., iv-vi.I956 (V.F.E. \& E. A.J.), also at the same site on Dolichos, vi.I929 (F.D. Golding).

This species does not fit into any of the North American species groups of Trialeurodes defined by Russell (I948). It was not recognizable from its original description and a relationship to $T$. vaporariorum had been tentatively suggested. It differs from that species in several important respects, notably the large setae at the base of the legs, the anterior rim of the orifice, and the relatively long operculum. The strong setae at the base of the legs are mentioned in the description of $T$. lubia, but 
the anterior rim around the vasiform orifice is confused in the figure of that species with the pockets of the eighth abdominal segment, and the internal opening of the orifice is apparently labelled as the operculum. The position of the sub-marginal disc pores relative to the sub-marginal papillae, a very useful character pointed out by Russell, was not indicated in the description of either species. T. desmodii is clearly widely distributed across Africa and the present author has recently received material apparently of this species from Bangalore, India. It seems possible that $T$. rara Singh (I93I) may eventually be found to be an older name for this insect, but the Indian Collection is not available.

\section{Trialeurodes hargreavesi Corbett, I935}

Material examined: Two pupal cases, the paratypes; Sierra Leone: Njala, on Lindernia diffusa, I9.xii.I932 (E. Hargreaves).

The paratypes of this species are too poor to attempt a redescription without additional material. The original figure does not agree completely with these two specimens, in particular the sub-marginal pores are arranged in quite distinct circular clusters involving from five to fifteen pores. The number varies in the two specimens, but more particularly, as Corbett figured, from anterior to posterior in the same specimen. Moreover the lingula tip is more rounded than the figure indicates and extends beyond the posterior margin of the orifice. The species is by no means a typical Trialeurodes, but is possibly related to the Indian species $T$. breyniae Singh (I93I).*

\section{Trialeurodes ricini (Misra, I924)}

Material examined: One pupal case, Nigeria: Ibadan, Moor Plantation, on Ipomoea batata, xii.Ig6o (M.O.E.) ; one pupal case, Akure, on a Labiate species, vii. $1956(V . F, E$.).

The identity of this species is not known for certain as the Indian collection of Singh is not available. The two specimens referred to above are provisionally identified as $T$. ricini as they have a uniform row of equal sized sub-marginal papillae, each with a pore at its base. Apart from this they are clearly very closely related to $T$. desmodii, with which species they have many characters in common.

REFERENCES

(**not seen by author)

**Ashmead, W. H. I885. Florida Dispatch.ns. 11. (ex Quaintance and Baker 1917).

Bemis, F.E. I904. The Aleyrodids, or mealy-winged flies of California, with reference to other American species. Proc. U.S. nat. Mus. $27: 47$ I-537, Pls. 26-37.

Cockerell, T. D. A. 1902. Classification of Aleyrodidae. Proc. Acad. nat. Sci. Philad. $54:$ 279-283, pl. I5.

Corbett, G. H. 1935 (August). On New Aleurodidae (Hem.). Ann. Mag. nat. Hist. (ro) 16: $240-252,7$ figs.

*A recent examination of the type material of Lipaleyrodes phyllanthi Takahashi, 1962, from Madagascar, has confirmed that $T$. hargreavesi should be placed in the genus Lipaleyrodes. 
Corbett, G: H. 1935 (November). Malayan Aleurodidae. J.F.M.S. Mus. $17: 722-852$, 105 figs.

— 1936. New Aleurodidae (Hem.). Proc. R. ent. Soc. Lond. (B) 5 : 18-22, 6 figs.

Dozier, H. L. 1928. Two new Aleyrodid (Citrus) pests from India and the South Pacific. J. agric. Res. 36 : IOOI-1005, 5 figs.

- 1934. Descriptions of new genera and species of African Aleyrodidae. Ann. Mag. nat. Hist. (10) $14:$ I $84-192,2$ pls., 2 figs.

El Kididi, I. \& Khalifer, A. 1962. A new Aleyrodid from the Sudan. Proc. R. ent. Soc. Lond. (B) $31: 47-51,6$ figs.

Gennadius, P. I889. Ellenike Georgia (Greek Agriculture) (Athens). pp. (I)-3.

Ghesquière, J., in Mayné, R. \& Ghesquière, J. I934. Hémiptères nuisables aux végétaux du Congo Belge. Ann. Gembl. $40: 4 \mathrm{I}$ pp, Io pls, I I figs.

Hussey, N. W. \& GuRneY, B. 1957. Trialeurodes sonchi Kotinsky a synonym of T. vaporariorum Westwood (Hem., Aleyrodidae). Ent. Mon. Mag. $93: 254$.

Kotinsky, J. 1907. Aleyrodidae of Hawaii and Fiji with descriptions of new species. Bull. Div. Ent. Hawaii. 2 : 93-103, pl. I.

Maskell, W. M. I896. Contributions towards a monograph of the Aleurodidae, a family of Hemiptera-Homoptera. Trans. N.Z. Inst. $28: 4$ I I-449.

Mimeur, J. M. I946. Neomaskellia bergii Signoret (Hemiptère-Aleurodidae) en A.O.F. Bull. Soc. Sci. nat. Maroc. $24: 89$.

Misra, C. 1924. The citrus whitefly, Dialeurodes citri, in India and its parasites, together with

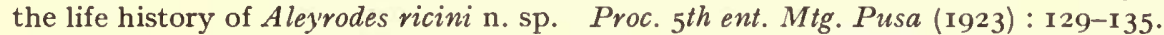

Mound, L. A. I96r. A new genus and four new species of whitefly from ferns (Homoptera, Aleyrodidae). Rev. Zool. Bot. afr. 64: 127-132.

- 1962. Studies on the olfaction and colour sensitivity of Bemisia tabaci (Genn.) (Homoptera, Aleyrodidae). Ent. exp. E appl. 5 :99-104.

— 1963. Host correlated variation in Bemisia tabaci (Gennadius) (Homoptera, Aleyrodidae). Proc. R. ent. Soc. Lond. (A) $38:$ I 7 I-180, 17 figs.

Newstean, R. igir. On a collection of Coccidae and Aleurodidae, chiefly African, in the collection of the Berlin Zoological Museum. Mitt. zool. Mus. Berl. 5 : 153-I 74.

- 1921. A new Southern Nigerian Aleurodes (Aleurodidae). Trans. R. ent. Soc. Lond. 1921 : $528-529$.

Pearson, E. O., in Hutchinson, J. B. \& Knight, R. L. I950. Response of cotton to leaf curl disease (Appendix on distribution of cotton virus and Bemisia in Africa). J. Genet. 50 : IOO-III.

Priesner, H. \& Hosny, M. 1934. Contributions to a knowledge of the whiteflies (Aleurodidae) of Egypt (III). Bull. Minist. Agric. Egypt. No. 145 : I I pp., 9 pls. I fig.

Quaintance, A. L. I90o. Contributions toward a monograph of the American Aleurodidae. Bull. U.S. Bur. Ent. $8: \mathrm{I}-43$, pls. I-8.

1903. New Oriental Aleurodidae. Canad. Ent. $35: 6 \mathrm{I}-64$.

Quaintance, A. L. \& Baker, A. C. 1913. Classification of the Aleyrodidae. Pt. I. Bull. U.S. Bur. Ent. 27 : I-93, 34 pls.

Pls. $34-35$.

I917. A contribution to our knowledge of the whiteflies of the sub-family Aleyrodinae (Aleyrodidae). Proc. U.S. nat. Mus. 51:335-445, Pls. 32-37.

Risbec, J., in Bouriguet, G. I954. Le vanillier et la vanille dans le monde. Edition Paul Lechevalier, Paris.

Russell, L. M. I948. The North American species of whiteflies of the genus Trialeurodes. Misc. Publ. U.S. Dep. Agric. $635: 85$ pp, 34 figs.

1958. Synonyms of Bemisia tabaci (Gennadius) (Homoptera, Aleyrodidae). Bull. Brooklyn ent. Soc. 52 : 122-123.

r960. A taxonomic study of the genus Corbettia Dozier. Rev. Zool. Bot. afr. 62 : I20-I37, 2 figs. 
Russell, L. M. 1962. New name combinations and notes on some African and Asian species of Aleyrodidae (Homoptera). Bull. Brooklyn ent. Soc. $57: 63-65$.

Signoret, V. 1868. Essai monographique sur les Aleurodes. Ann. Soc. ent. Fr. $8:$ 369-402. SiNGH, K. I93I. A contribution to our knowledge of the Aleyrodidae (whiteflies) of India. Mem. Dep. Agric. India. Ent. $12: 98$ pp, 37 pls.

I940. Notes on Aleurodidae (Rhynchota) from India. II. Rec. Indian Mus. $42: 453-$ 456.

Takahashi, R. 1932. Aleyrodidae of Formosa I. Rept. Dept. Agric. Formosa 59:57 pp, 34 figs.

I95I. Some species of Aleyrodidae (Homoptera) from Madagascar with a species from Mauritius. Mèm. Inst. sci. Madagascar 6A : 353-385, I9 figs.

I955. Some species of Aleyrodidae from Madagascar III. (Homoptera). Mém. Inst. sci. Madagascar 6E : 375-44I, 42 figs.

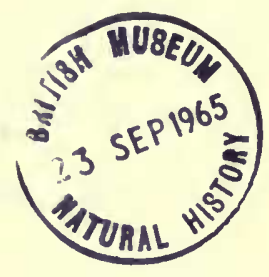

